\title{
32
}

\section{Heat Shock Proteins (Hsps) Mediated Signalling Pathways During Abiotic Stress Conditions}

\author{
Kummari Divya, Pooja Bhatnagar-Mathur, \\ Kiran K. Sharma and Palakolanu Sudhakar Reddy
}

Cell, Molecular Biology \& Genetic Engineering Group, Research Program-Genetic Gains, International Crops Research Institute for the Semi-Arid Tropics (ICRISAT), Patancheru, Hyderabad, Telangana, India

\section{O U T L I N E}

32.1 Introduction

32.2 A General Account on Heat Shock Proteins 32.2.1 Small Heat Shock Proteins

32.3 Heat Shock Protein Induction Phenomena in Plants

32.4 Abiotic Stresses Induce the Heat Shock Protein-Mediated Signaling Pathways

32.4.1 Reactive Oxygen Species

32.4.2 Mitogen Activated Protein Kinases

32.4.3 Calcium and Calcium-Regulated

Proteins
499

501

501
32.5 Crosstalk Between Reactive Oxygen Species, Mitogen Activated Protein Kinases Cascades, $\mathrm{Ca}^{+2}$ and Heat Shock Factor/Heat Shock Proteins

32.6 Genetic Engineering of Heat Shock Proteins Signaling Molecules

32.7 Conclusions and Future Perspectives

Acknowledgments

References

\subsection{INTRODUCTION}

During their entire life span plants encounter several abiotic stresses and also experience various complex environmental interactions comprising multiple factors. Plants have evolved with specific adaptive mechanisms to cope with stress conditions (Meena et al., 2017; Khan and Khan, 2017). When plants are exposed to various stresses plant metabolism is disturbed (Massad et al., 2012; Khan et al., 2012, 2013; Per et al., 2017, 2018), which eventually affects the plants' growth and productivity up to $>50 \%$ (Wang et al., 2003; Shao et al., 2008). A crucial step in plants' stress tolerance mechanism to abiotic stress is the timely recognition of the stress signals and activation of the composite signaling cascades of defense in a specific and efficient manner (Chinnusamy et al., 2004; AbouQamar et al., 2009; Andreasson and Ellis, 2010; Khan et al., 2016). To protect against different stresses, plants activate several specific stress-responsive mechanisms by perceiving 
the stress signals, then producing molecules through signal transduction by up/down regulation of the many sets of mechanisms and their genes (Wang et al., 2003; Per et al., 2017, 2018). Products of stress-induced genes are classified into two major groups: (1) proteins, which directly protect against stresses include chaperones, Lea proteins, antifreeze proteins, and detoxification enzymes; and (2) some of which regulate gene expression and signal transduction pathways include transcription factors (TFs), protein kinases, and enzymes (Basu and Roychoudhury, 2014). Among them, Hsps come under the umbrella of chaperones, which show important stress-related chaperone functions in plants under abiotic stress conditions (Hendrick and Hartl, 1993; Bartels et al., 2007; Reddy et al., 2010, 2011, 2014a,b, 2016). Chaperones include specific stress-related proteins and are involved in protein synthesis, targeting, maturation, degradation, membrane stabilization, and protein renaturation (Reddy et al., 2014, 2016; Díaz-Villanueva et al., 2015). In the presence of abiotic stresses, there is an assembly of some chemical messengers that positively affects a plant's stimulus to the stresses and hence protects it from different aggressors (Pastori and Foyer, 2002; Rasmussen et al., 2013; Khan et al., 2015, 2016). Plants' reflex in adverse stress conditions is by altering the expression of a complex array of genes and elucidation of the biochemical and molecular pathways (Fig. 32.1). Genes associated with these pathways have been the foremost focus of research over the last two to three decades and the mechanisms by which these genes and their products interact remain relatively less focused.

Commonly, Hsps shield cells from injury and assist in revival and endurance after a return to normal growth conditions (Al-Whaibi, 2011). Under stress, by default Hsps play as molecular chaperones whereas under nonthermal stress their function can be changed (Timperio et al., 2008). It is implied that Hsps play a consistent role as molecular chaperones by regulating the enfolding, aggregation, transport, and degradation of the proteins in the plants ( $\mathrm{Hu}$ et al., 2009; Tripp et al., 2009; Gupta et al., 2010; Al-Whaibi, 2011; Reddy et al., 2010, 2011, 2016). Based on their protein size, Hsps can be divided into five families that have been shown to have important stress-related chaperone functions in the plants (Török et al., 2001; Reddy et al., 2016). Each Hsp family has a distinctive mechanism and the role of each family is summarized in the subsequent sections (Table 32.1). Hsps' function in signal transduction has been established from experimental results that Hsp90 and Hsp70 proteins are associated with a number of signaling molecules, including v-Src, Raf1, Akt, and steroid receptor protein kinases like MAPK and $\mathrm{Ca}^{+2}$ (Sato et al., 2000; Nollen and Morimoto, 2002; Wang and Huang, 2017). The components or signaling molecules and cochaperones of both ABA-dependent and independent signaling pathways that activate the TFs needs to be defined genetically for assessing whether a signaling pathway is specific to a particular stress or is involved in crosstalk with

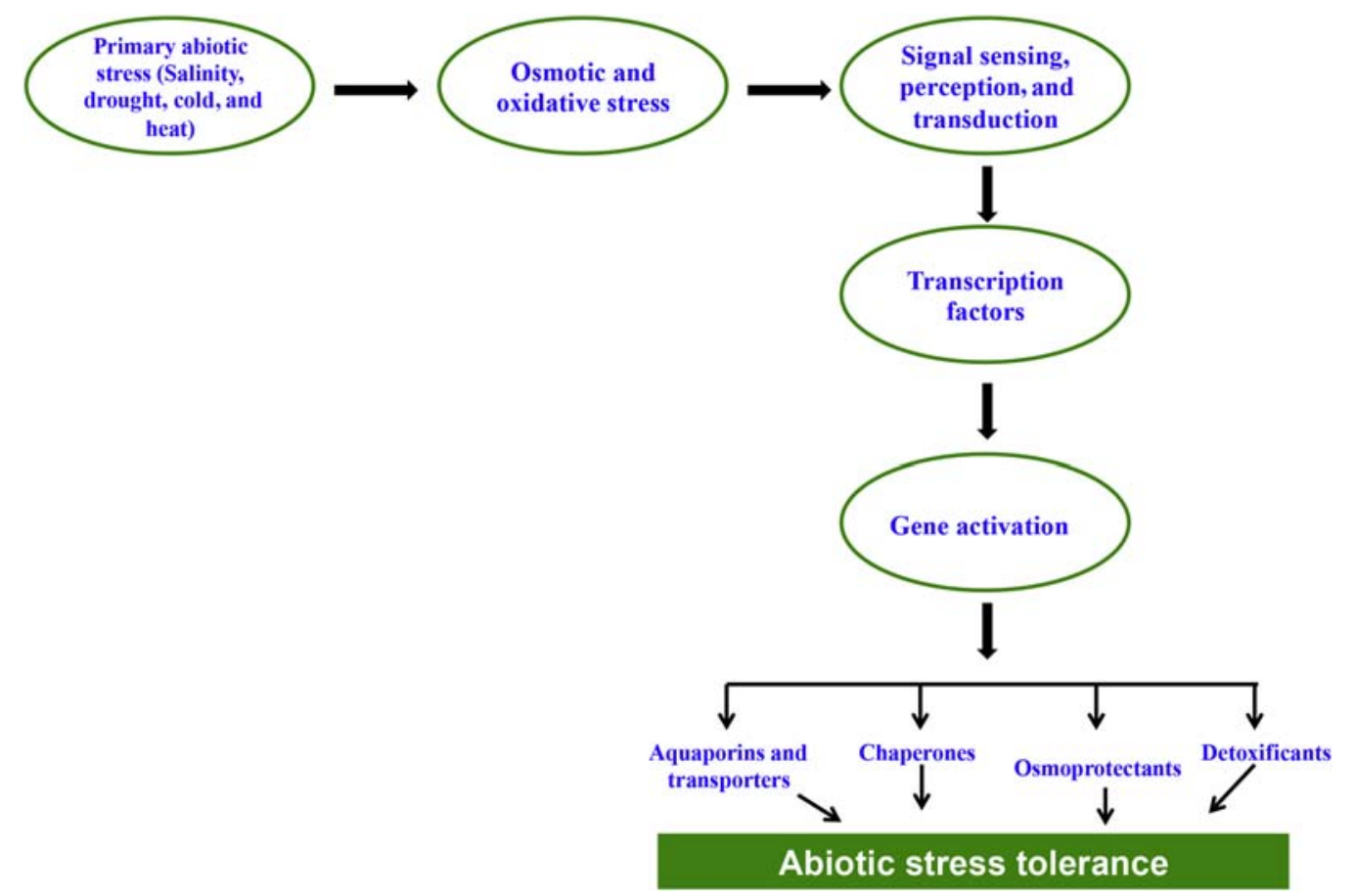

FIGURE 32.1 Complex signaling network of the plant response against different abiotic stress. 
TABLE 32.1 Different Classes of Heat Shock Protein Families, Their Location and Functions

\begin{tabular}{|c|c|c|c|}
\hline Classes & $\begin{array}{l}\text { Representative } \\
\text { members }\end{array}$ & Location & Major functions \\
\hline Hsp100/Clp & Hsp100 & $\begin{array}{l}\text { Cytosol, } \\
\text { mitochondria }\end{array}$ & $\begin{array}{l}\text { Disaggregation, } \\
\text { unfolding }\end{array}$ \\
\hline Subfamily: & & Chloroplast & \\
\hline \multirow[t]{2}{*}{ Class I } & $\mathrm{ClpB}, \mathrm{ClpA} / \mathrm{C}$ & Chloroplast & \\
\hline & ClpD & & \\
\hline \multirow[t]{2}{*}{ Class II } & ClpM, ClpN & & \\
\hline & ClpX, ClpY & & \\
\hline \multirow[t]{4}{*}{ Hsp90 } & Hsp90 & Cytosol & \multirow{4}{*}{$\begin{array}{l}\text { Facilitating } \\
\text { maturation of } \\
\text { signaling molecules, } \\
\text { genetic buffering }\end{array}$} \\
\hline & & Chloroplast & \\
\hline & & Mitochondria & \\
\hline & & $\begin{array}{l}\text { Endoplasmic } \\
\text { reticulum }\end{array}$ & \\
\hline Hsp70 & Hsp/Hsc70 & Cytosol & \multirow{4}{*}{$\begin{array}{l}\text { Preventing } \\
\text { aggregation, assisting } \\
\text { refolding, protein } \\
\text { import and } \\
\text { translocation, signal } \\
\text { transduction, and } \\
\text { transcriptional } \\
\text { activation }\end{array}$} \\
\hline Subfamily: & Hsp70 & $\begin{array}{l}\text { Chloroplast, } \\
\text { mitochondria }\end{array}$ & \\
\hline \multirow[t]{2}{*}{ DnaK } & Bip & $\begin{array}{l}\text { Endoplasmic } \\
\text { reticulum }\end{array}$ & \\
\hline & Hsp91 & Cytosol & \\
\hline \multicolumn{4}{|l|}{ Hsp110/SSE } \\
\hline \multirow[t]{2}{*}{$\begin{array}{l}\text { Chaperonin/ } \\
\text { Hsp60 }\end{array}$} & Cpn60 & $\begin{array}{l}\text { Chloroplast, } \\
\text { mitochondria }\end{array}$ & \multirow[t]{2}{*}{$\begin{array}{l}\text { Folding and assisting } \\
\text { refolding }\end{array}$} \\
\hline & CCT & Cytosol & \\
\hline \multicolumn{4}{|l|}{ Subfamily: } \\
\hline \multicolumn{4}{|l|}{ Group I } \\
\hline \multicolumn{4}{|l|}{ Group II } \\
\hline sHsp & & Cytosol & \multirow{9}{*}{$\begin{array}{l}\text { Preventing } \\
\text { aggregation, } \\
\text { stabilizing nonnative } \\
\text { proteins }\end{array}$} \\
\hline Subfamily: & & Cytosol & \\
\hline I & Hsp17.6 & Chloroplast & \\
\hline II & Hsp17.9 & $\begin{array}{l}\text { Endoplasmic } \\
\text { reticulum }\end{array}$ & \\
\hline \multirow[t]{2}{*}{ III } & Hsp21 & Mitochondria & \\
\hline & Hsp26.2 & Membrane & \\
\hline IV & Hsp22 & & \\
\hline V & Hsp23 & & \\
\hline VI & Hsp22.3 & & \\
\hline
\end{tabular}

other pathways (Yoshida et al., 2014). Signal transduction in plants under various environmental stresses have been divided into three major types, that is, (1) osmotic/oxidative stress signaling through MAP kinases, (2) $\mathrm{Ca}^{+2}$-dependent signaling, and (3) reactive oxygen species (ROS) signaling (Xiong et al., 2002). Resolving the mechanisms that control $\mathrm{Ca}^{+2}$, MAPK, and ROS signaling in cells during abiotic stress can provide an efficient way to increase plant tolerance to the environmental stresses. These signaling mechanisms are emphasized more in the following sections pertaining to Hsps as well as the functionality of different Hsps and their crosstalk in different signaling mechanisms.

\subsection{A GENERAL ACCOUNT ON HEAT SHOCK PROTEINS}

Abiotic stresses induce a set of special class of proteins called heat shock proteins (Hsps) or stressinduced proteins (Reddy et al., 2016). Based on their protein size, Hsps were classified into five subfamilies including small Hsp (sHsp), Chaperonins, Hsp70, Hsp90, and Hsp100 (Wang et al., 2004; Kotak et al., 2007; Gupta et al., 2010; Reddy et al., 2016). Hsps are involved in maintaining the cellular equilibrium, protein conformation, preventing aggregation, and hence preserving the nonnative protein in a competent state for further remodeling, which is attained by other Hsps/chaperones (Lindquist, 1986; Wang et al., 2004). The denatured or incorrectly folded proteins make aggregates, and they can be resolubilized by Hsp100/ Clp followed by refolding, or degraded by proteases (Mishra et al., 2016). Some Hsps/chaperones (e.g., Hsp70, Hsp90) accompany the signal transduction and transcription switch on the synthesis of Hsps (Wang et al., 2004; Al-Whaibi, 2011). The detailed role of each Hsp family is emphasized in the subsequent sections of this chapter.

\subsubsection{Small Heat Shock Proteins}

Small heat shock proteins (sHsps) have a unique alpha-crystallin domain (ACD) containing 80-100 amino acid residues located in the C-terminal region (Seo et al., 2006). sHsps have several characteristic features including the degradation of the proteins that cannot fold back and ATP independent chaperonic function (Miernyk, 1999; Reddy et al., 2014, 2015). The sHsps cannot refold nonnative proteins, but they can bind to partly folded or denatured substrate proteins and prevent permanent unfolding or incorrect protein aggregation (Sun et al., 2002). Neoteric study revealed that under in vitro conditions, sHsp18.1 from Pisum sativum as well as the sHsp16.6 from Synechocystis sp. PCC6803 binds to unfolded proteins and allows further refolding by Hsp70/Hsp100 complexes (Mogk et al., 2003). Studies in apple indicated that the 
mitochondrial sHsp protects the NADDH:ubiquinone oxidoreductase (complex I) during heat stress (Downs and Heckathorn, 1998). AsHsp17 modulates the expression of photosynthetic genes through ABAdependent and independent signaling pathways (Sun et al., 2016). In addition to abiotic stress, sHsps also play a role in biotic stress by associating with Hsp70/ Hsp40 chaperone complex (Rousch et al., 2004). Another sHsp20 is known to specifically interact with I-2, which confers resistance to Fusarium oxysporum (Simons et al., 1998).

\subsubsection{Chaperonins}

Hsp60 comes under chaperonins and is involved in facilitating the vast range of newly synthesized proteins, and translocates to organelles such as chloroplasts and mitochondria (Bukau and Horwich, 1998; Wang et al., 2004). Plant chaperonins commonly play a major role in assisting the plastid proteins such as Rubisco (Tompa and Kovacs, 2010). Hsp60 family proteins bind to different types of proteins after their transcription and prior to folding to avoid their aggregation (Parsell and Lindquist, 1993). Arabidopsis chlCpn60a mutated species was shown to exhibit defects in chloroplast development and subsequently in the plant development (Apuya et al., 2001). Antisense Cpn60b in transgenic tobacco plants showed drastic phenotypic alterations, including slow growth, delayed flowering, stunting, and leaf chlorosis (Zabaleta et al., 1994). Hsp10 is a cochaperone that functions together with Hsp60 in an ATP-dependent manner and helps in folding, assembly, and sorting of proteins (Bukau and Horwich, 1998). The Hsp60-Hsp10 complex enhances the osmotic as well as salt stress tolerance in transformed E. coli and yeast cells (Wang et al., 2004).

\subsubsection{Heat Shock Protein 70}

The abundant Hsps present in eukaryotic cell is Hsp70 proteins. Hsp70 proteins play a role as chaperones for newly synthesized proteins to stop their accumulations as aggregates, and assist in accurate folding and help in translocation (Su and Li, 2008; Wang et al., 2014). Hsp70 protein binds in an ATP-dependent manner to hydrophobic patches of moderate unfolded proteins and prevent protein aggregation (Mayer and Bukau, 2005; Reddy et al., 2010). Hsp70 along with other Hsps behave as molecular chaperones and play an important role in protecting plant cells from the detrimental effects of abiotic stresses including heat stress (Rousch et al., 2004). Hsp70-sHsp17.6 chaperone complex may play a role in cross adaptation to temperature stress induced by heat or cold pretreatment in grape plants (Zhang et al., 2008). Under heat stress, Hsc70 cognates are essential for general cellular functions due to their involvement in the control of protein homeostasis, categorizing of proteins by interaction with mitochondrial and chloroplast protein import complexes, and making a connection to the proteasomal degradation pathway through ubiquitin (Hartl and Hayer-Hartl, 2002; Mirus and Schleiff, 2009). Chaperone complex (SGT1b-Hsp70-Hsp90) with other client protein (COI1) helps in hormone signaling by stabilizing the client protein. The Came/AtBAG5/ Hsc70 signaling complex plays a pivotal role in modulating the plant senescence (Li et al., 2016). Salicylic acid (SA) is a crucial molecule in signaling, which activates several plant defense mechanisms, and enhances the expression of Hsp70, which further helps in modulation of the heat shock response (HSR) in tomato seedlings (Cronjé et al., 2004), tobacco protoplasts (Cronjé et al., 2004), and seedlings of Arabidopsis. Another receptor that could straight away bind to mycobacterial Hsp70 is the chemokine receptor CCRS, which has a considerable significance for signaling cascades induced by Hsps (Floto et al., 2006). Hsp70 protein forms guidance complex with other proteins and directs import bound to the protein precursor to be transferred through the membranes into the organelles such as chloroplast and mitochondria (JacksonConstan et al., 2001). Other studies indicate that Hsp70B found in the stroma of chloroplasts takes part in photoprotection and the repairing of photosystem II during and after the photoinhibition (Schroda et al., 1999). Study on A. thaliana also indicated the necessity of Hsp70 found in the stroma of chloroplast for the differentiation of germinating seeds and its tolerance of heat stress (Su and Li, 2008).

\subsubsection{Heat Shock Protein 90}

Hsp90 class proteins are the most abundant class of Hsps with $\sim 1 \%$ of total proteins in prokaryotic and eukaryotic cells. Hsp90 increases up to $4 \%-6 \%$ of total protein under elevated heat stress conditions (Wegele et al., 2004). Hsp90 proteins majorly reside in the cytoplasm, and are rarely seen in the other organelles like endoplasmic reticulum (ER), mitochondria, and chloroplasts (Hao et al., 2010; Reddy et al., 2011). Hsp90 proteins are seen to interact and bind with Hsp70 in many chaperone complexes in signaling and trafficking (Pratt and Toft, 2003). Hsp90 proteins are involved indirectly along with other proteins in the process of signal transduction. Hence, losing the activity may lead to different disturbances in cells. Hsp90 interacting proteins are categorized into three types, which include auxiliary proteins (cochaperones), regulatory factors (regulators), and substrate proteins (substrates) (Xu et al., 2012). Accessory proteins are involved in the modulation of ATP enzymatic function of Hsp90s in cytoplasm and help in interactions between Hsp90s and 
the substrates (Johnson and Brown, 2009; Zuehlke and Johnson, 2010). All Hsp90 proteins have the TPR-binding site in their structure and help in interaction of the TPR domain-containing proteins (Aviezer-Hagai et al., 2007). Under control conditions, Arabidopsis ROF1 interacts with Hsp90 through the TPR domain and targets into the cytoplasm (Aviezer-Hagai et al., 2007) but under heat stress, ROF1-Hsp90 makes a complex with HsfA2 and migrates to the nucleus and regulates sHsp transcription to increase heat tolerance (Meiri and Breiman, 2009). In control state, A. thaliana Hsp90 negatively inhibited Hsf, but under heat stress modulated positively (Yamada et al., 2007). The Hsp90-TIR1 module integrates the temperature and auxin signaling to regulate plant development (Wang et al., 2016). Hsp90s chaperonic activity mainly depends on phosphorylation and stimulates heme to modulate heme-regulated inhibitor (HRI) through casein kinase II or secondary phosphorylation (Szyszka Kramer and Hardesty, 1989). Hsp90s affect the folding and activation of a wide variety of substrate proteins, most of which are kinases and TFs involved in signal transduction and regulatory processes (Pratt et al., 2004; Krukenberg et al., 2011). Hsp90 has also been seen to function in brassinosteroid (BR) signaling (Samakovli et al., 2014). This highlights the importance of the Hsp90s' role in signaling of hormones in plants and animals. Gene silencing of RPS4 results in cell death, which is dependent on the three plant signaling components, EDS1, SGT1, and Hsp90 (Zhang et al., 2004). These studies substantiate that Hsp90 is an important signaling component under abiotic stress conditions.

\subsubsection{Heat Shock Protein 100}

The Hsp100 family belongs to the AAA ATPase super family with a wide range of functional properties (Agarwal et al., 2001). Besides playing a role in protein aggregation and misfolding, the Hsp100 families are seen to be crucial for disaggregation and/or degradation of proteins (Singh and Grover, 2010). Removal of degraded polypeptides, which are harmful due to misfolding, accumulation, or denaturation is crucial for maintaining equilibrium of the cells. A characteristic activity of Hsp100 is a reactivation of accumulated proteins by resolubilization of nonfunctional protein aggregates as well as in assisting to degrade damaged and irreparable polypeptides (Parsell and Lindquist, 1993; Bösl et al., 2006; Kim et al., 2007). Hsp101 is also seen to be playing a crucial role in high temperature stress tolerance, which can be used in genetic engineering of plants. This may improve sustenance during situations of acute environmental stress (Queitsch et al., 2000).

\subsubsection{Heat Shock Transcription Factors}

In the plant genome, $\sim 7 \%$ of the coding sequences constitute TFs and among them, the majority are of large gene families in comparison with their counterparts in animals and yeasts, such as Hsfs (Udvardi et al., 2007). To survive under adverse conditions, plants have greater number of Hsfs in comparison with other systems like mammalian cells. Hsfs belong to a multigenic family with more than 21 in Arabidopsis (Scharf et al., 2012), 24 in tomato (Fragkostefanakis et al., 2015), 52 in soybean (Scharf et al., 2012), and at least 56 in wheat (Xue et al., 2014) are anticipated and may be involved in stress responsiveness. Hsfs are seen to be involved in plant response to various abiotic stress conditions. Hsfs specifically bind to the heat stress elements (HSEs) present in the promoters of target genes, which further activate the genes (Baniwal et al., 2004; Sakurai and Enoki, 2010; Scharf et al., 2012). In tomato, only two Hsfs, HsfA2 and HsfB1, are induced by heat (Scharf et al., 1990), whose expression is modulated by HsfA1 (Mishra et al., 2002). In fact, the interaction of HsfA2 with HsfA1 is required for the colocalization of HsfA2 into the nucleus (Scharf et al., 1998). HsfA2 is the most predominant Hsf during heat stress conditions (Mishra et al., 2002). Under heat stress, AtHsfA1d and AtHsfA1e together bind to the HSE cis-element of the AtHsfA2 gene and activate the AtHsfA2 expression (Nishizawa-Yokoi et al., 2011). Hsfs playing a role in drought and salinity stresses are modulated by ABA-dependent and ABA-independent signaling pathways (Yoshida et al., 2008). At high temperature, the expression of the Hsps is modulated by Hsfs (Saidi et al., 2011; Scharf et al., 2012). Further, Hsfs translocate to the nucleus in heat stress where they bind to HSEs of respective promoter regions of Hsp genes (Voellmy and Boellmann, 2007; Scharf et al., 2012). The alternative regulatory systems for the activation of different Hsp expression are seen to be operated in plants by modulating WRKY, DREB2A, and DREB2C TFs (Scharf et al., 2012). Besides WRKY, there are more than 90 TFs in Arabidopsis that have the binding sites for CAM that comprise the Calmodulinbinding transcription activator (CAMTA). Expression of the genes coding to these proteins increases in response to heat conditions (Reddy et al., 2011), but it is unknown if this increase is important for Hsp expression or not. HsfA2, HsfA3, and HsfA7a of Arabidopsis are considered as the strongest activators of HS transcription during recovery and are responsible for the heat-acclimation phenotype (Charng et al., 2007; Nishizawa et al., 2006; Schramm et al., 2008). Some studies have also concluded that Hsfs play a role in the sensing of ROS. Mittler and Zilinskas (1992) and Storozhenko et al. (1998) have revealed the presence of 
a HSF-binding sequence in the 5 ' region of the gene that codes for $\mathrm{H}_{2} \mathrm{O}_{2}$-scavenging enzyme Apx1. In addition, Hsf and HSE (PgApx1) specificity to each other and their expression profile shows a critical interlink in heat and oxidative stress signaling pathways, which are known to play an important part in understanding the mechanisms involved in plant abiotic stress tolerance (Reddy et al., 2009). Furthermore, HsfA4A carries out the function of Arabidopsis $\mathrm{H}_{2} \mathrm{O}_{2}$ under oxidative stress (Miller and Mittler, 2006). HvHsfB2c is coexpressed in the main hub of sHsps and hence it may be modulating the expression levels of different sHsps in barley (Reddy et al., 2014). DREB2A signaling is mediated by HsfA3, which again induces the expression of Hsfs (Schramm et al., 2008; Yoshida et al., 2008). It has been shown that calmodulin is an essential component in Arabidopsis signal transduction, and with the help of a yeast two-hybrid assay, it has been demonstrated that calmodulin-binding protein kinase 3 interacts with heat shock factor (Hsf) AtHsfAla (Liu et al., 2008). Wang and Huang (2017) also demonstrated that transcriptional regulation of HsfA2c-mediated heat tolerance involving lipid and calcium signaling pathways in tall fescue.

\subsection{HEAT SHOCK PROTEIN INDUCTION PHENOMENA IN PLANTS}

Hsp synthesis in plants, including rice, Medicago and tomato was qualitatively and quantitatively dependent on the type of condition and nature of tissue (Hernandez and Vierling, 1993; Pareek et al., 1998; $\mathrm{Hu}$ et al., 2009; Fragkostefanakis et al., 2015; Zhou et al., 2016). A further study on expression of cytoplasmic class of proteins in leaves, flowers, and developing seed pods in Medicago sativa was carried out. Results indicated the recurrent formation of these proteins in flowers and buds, but no expression in the leaves (Hernandez and Vierling, 1993). Heat stress is an increase in temperature for a short term at $37-38^{\circ} \mathrm{C}$, which has no negative impact, but enhances the ability of plants to sustain the subsequent damaging heat treatment, termed heat shock; this phenomenon is known as induced or acquired thermotolerance (Saidi et al., 2011). The induced thermotolerance of plants is seen to be dependent on the expression of Hsps. Plant Hsp101 is seen to play the main role in induced thermotolerance (Queitsch et al., 2000). Expression of Hsp90 in rice plant indicated that the Hsp90 was present after $2 \mathrm{~h}$ of heat stress (from $28^{\circ} \mathrm{C}$ to $45^{\circ} \mathrm{C}$ ), and its quantity was high and stable even after heat stress $(4 \mathrm{~h})$ and after return to normal conditions. It was also found that Hsp90 (Hsp85 and Hsp87) could be induced by other than heat stress, such as salinity, drought, and cold (Pareek et al., 1998). Hsp100/ClpB proteins tend to interact tightly with
sHsps that are incorporated into the protein aggregates under heat shock, thus promoting the disaggregation activity of Hsp100/ClpB (Rikhvanov et al., 2007). Hu et al. (2009) examined a global expression profiling with heat stressed rice seedling, and then compared the results with the previous rice data under cold, drought, and salt stresses. They found that Hsps and Hsfs might be important molecules in crosstalk of different stress signal transduction networks. The expression of Hsps and its factors' Hsfs was induced largely by heat, cold, salinity, and osmotic stresses. The response to other stress factors depended on protein class and tissue. For example, under stress, high expression response for class Hsp20 was recorded with high similarity of their information. Wounding the roots of the plant stimulated (after $12 \mathrm{~h}$ ) the expression of several genes, including Hsp20, Hsp70, and Hsp100. High expression of Hsps and Hsfs was observed under UV-B stress in aerial tissues (shoot), but in nonaerial tissues (root system) there was no expression (Swindell et al., 2007).

\subsection{ABIOTIC STRESSES INDUCE THE HEAT SHOCK PROTEIN-MEDIATED SIGNALING PATHWAYS}

Abiotic stress response of plants is governed through the signaling pathways knitted at the cellular as well as molecular levels (Knight and Knight, 2001). Perception of abiotic stress initiates the signals that activate downstream signaling cascades and transcriptional controls and simultaneous pathways (Wang et al., 2003; Vij and Tyagi, 2007). The first step in the signal transduction pathway is the perception of the signal, which is carried out by receptors/sensors as phytochromes, histidine kinases and receptor-like kinases, G-protein-coupled receptors, and hormones. And then, secondary signaling molecules such as inositol phosphatase, ROS, and ABA are produced. Eventually, the secondary moleculemediated modulation of intracellular $\mathrm{Ca}^{2+}$ level activates protein phosphorylation cascades (i.e., MAP kinases, CDP kinases, protein phosphatase, SOS3/protein kinase, etc.), TFs, and stress-responsive genes (Boguszewska and Zagdańska, 2012; Gong et al., 2013). For genetically engineering stress tolerance traits in plants, proper insights of both endpoints and the precession are required for signaling pathways (Chinnusamy et al., 2004; Akpinar et al., 2012). Taking into account the first principle concepts and the developments of late, succeeding sections briefly give an insight into the significance of ROS, calcium and calcium-regulated proteins, and MAPK cascades in signaling pathways in plants under different abiotic stresses. The different signaling molecules and varied Hsps and Hsfs activated in response to elevated temperatures are given in Table 32.2. 
TABLE 32.2 Summary of the Key Signaling Mechanisms Modulating the Expression of Heat Shock Proteins in Plants

\begin{tabular}{|c|c|c|c|c|}
\hline $\begin{array}{l}\text { Signaling } \\
\text { component }\end{array}$ & Plant & $\begin{array}{l}\text { Treatment } \\
\left({ }^{\circ} \mathrm{C}\right)\end{array}$ & Remarks & References \\
\hline \multirow[t]{7}{*}{$\begin{array}{l}\text { Membrane and } \\
\mathrm{Ca}^{2+}\end{array}$} & Arabidopsis & $\begin{array}{l}22 \\
37\end{array}$ & $\begin{array}{l}\text { Induction of AtHsp } 18.2 \text { triggered by } \mathrm{Ca}^{2+} \text { and inhibited by Ca channel } \\
\text { blockers and EGTA }\end{array}$ & Liu et al. (2005) \\
\hline & \multirow[t]{2}{*}{ Tobacco } & 25 & $\begin{array}{l}\text { Hsp70 induced by membrane fluidizers and prevented by membrane } \\
\text { rigidifiers }\end{array}$ & \multirow[t]{2}{*}{$\begin{array}{l}\text { Suri and Dhindsa } \\
\text { (2008) }\end{array}$} \\
\hline & & $>38$ & Acquired thermotolerance diminished by EGTA and enhanced by $\mathrm{Ca}^{2+}$ & \\
\hline & Alfalfa & 37 & $\mathrm{Ca}^{2+}$ require for MAPK induction & $\begin{array}{l}\text { Sangwan et al. } \\
\text { (2002) }\end{array}$ \\
\hline & Maize & 27 & DNA-binding activity of Hsfs induced by $\mathrm{Ca}^{2+}$ & Li et al. (2004) \\
\hline & \multirow[t]{2}{*}{ Physcomitrella } & 22 & $\begin{array}{l}\text { Membrane fluidizers induced } \mathrm{Ca}^{2+} \text { influx, triggered HSR and enhanced } \\
\text { thermotolerance }\end{array}$ & \multirow[t]{2}{*}{ Saidi et al. (2009) } \\
\hline & & $>27$ & $\begin{array}{l}\text { Elicited } \mathrm{Ca}^{2+} \text { influx. Blocking } \mathrm{Ca}^{2+} \text { entry abolished the expression of } \\
\text { Hsps and reduced thermotolerance }\end{array}$ & \\
\hline \multirow[t]{6}{*}{$\begin{array}{l}\text { Calmodulin and } \\
\text { kinase }\end{array}$} & \multirow[t]{2}{*}{ Arabidopsis } & 37 & $\begin{array}{l}\text { AtCaM3 induced by elevated temperature. DNA-binding activity of } \\
\text { Hsfs reduced in cam3 mutant }\end{array}$ & Zhang et al. (2009) \\
\hline & & 37 & $\begin{array}{l}\text { At HsfA1 a specifically phosphorylated by At CBK3in the presence of } \\
\mathrm{CaM} \text { and } \mathrm{Ca}^{2+} \text {; binding activity of Hsfs to HSEs impaired in AtCBK3 } \\
\text { mutants and improved in the overexpressors; accumulation of Hsps } \\
\text { reduced in AtCBK3 mutants and enhanced in the overexpressors }\end{array}$ & Liu et al. (2008) \\
\hline & Tobacco & 37 & Hsp70 accumulation repressed by MAPKK inhibitors & \\
\hline & Maize & 27 & $\begin{array}{l}\text { DNA-binding activity of Hsfs induced by CaM and reduced by CaM } \\
\text { antagonist }\end{array}$ & Li et al. (2004) \\
\hline & Wheat & 37 & CaM antagonists decreased Hsp26 and Hsp70 expression & Liu et al. (2003) \\
\hline & Physcomitrella & 36 & $\begin{array}{l}\text { Pretreatment with kinase inhibitor reduced HSR and negatively affected } \\
\text { thermotolerance }\end{array}$ & Saidi et al. (2009) \\
\hline \multirow[t]{7}{*}{$\mathrm{H}_{2} \mathrm{O}_{2}$ and $\mathrm{NO}$} & \multirow[t]{5}{*}{ Arabidopsis } & 20 & $\begin{array}{l}\text { DNA-binding activity of Hsfs occurred in protein extracts from } \mathrm{H}_{2} \mathrm{O}_{2}- \\
\text { treated cells }\end{array}$ & $\begin{array}{l}\text { Volkov et al. } \\
\text { (2006) }\end{array}$ \\
\hline & & 23 & HsfA2 and Hsp25 were induced by treatment with $\mathrm{H}_{2} \mathrm{O}_{2}$ & \multirow[t]{2}{*}{ Banti et al. (2010) } \\
\hline & & 20 & Exposure to $\mathrm{H}_{2} \mathrm{O}_{2}$ induced expression of hsp17.6 and hsp18.2 & \\
\hline & & 37 & $\begin{array}{l}\text { Heat increased endogenous } \mathrm{H}_{2} \mathrm{O}_{2} \text { levels. } \\
\text { Hsp expression is reduced by peroxide scavenger; peroxide scavenger } \\
\text { blocked Hsf DNA-binding activity }\end{array}$ & $\begin{array}{l}\text { Volkov et al. } \\
\text { (2006) }\end{array}$ \\
\hline & & 37 & $\begin{array}{l}\text { DNA-binding activity of Hsfs and Hsp18.2 expression were reduced in } \\
\text { noa1 mutant and rescued by the addition of an NO donor }\end{array}$ & Xuan et al. (2010) \\
\hline & \multirow[t]{2}{*}{ Tobacco } & 45 & Endogenous NO levels increased during heat shock & Gould et al. (2003) \\
\hline & & 36 & Small Hsp induction reduced by inhibitor of $\mathrm{H}_{2} \mathrm{O}_{2}$ generation & $\begin{array}{l}\text { Königshofer et al. } \\
\text { (2008) }\end{array}$ \\
\hline \multirow[t]{3}{*}{$\begin{array}{l}\text { Cytoskeletonand } \\
\text { protein } \\
\text { denaturation }\end{array}$} & Arabidopsis & 20 & $\begin{array}{l}\text { Expression of HsfA2, Hsp70A, and small Hsps induced by chemical } \\
\text { generation of misfolded AZC-mediated Hsp70A expression reduced in } \\
\text { hsfA2 mutant }\end{array}$ & Sugio et al. (2009) \\
\hline & \multirow[t]{2}{*}{ Tobacco } & 25 & $\begin{array}{l}\text { Microfilament and microtubule destabilizers induced Hsp70 } \\
\text { accumulations }\end{array}$ & \multirow[t]{2}{*}{$\begin{array}{l}\text { Suri and Dhindsa } \\
\text { (2008) }\end{array}$} \\
\hline & & 37 & $\begin{array}{l}\text { Hsp70 accumulation repressed by microfilament and microtubule } \\
\text { stabilizers }\end{array}$ & \\
\hline
\end{tabular}


TABLE 32.2 (Continued)

\begin{tabular}{|c|c|c|c|c|}
\hline $\begin{array}{l}\text { Signaling } \\
\text { component }\end{array}$ & Plant & $\begin{array}{l}\text { Treatment } \\
\left({ }^{\circ} \mathrm{C}\right)\end{array}$ & Remarks & References \\
\hline & Rice & 28 & Activation of Oshsp17.3 promoter induced by AZC & Guan et al. (2010) \\
\hline & Physcomitrella & 40 & $\begin{array}{l}\text { Heat-denatured luciferase was not sufficient to induce Hsps when } \\
\text { extracellular } \mathrm{Ca}^{2+} \text { was immobilized }\end{array}$ & Saidi et al. (2009) \\
\hline \multirow[t]{2}{*}{ Hsp90 inhibition } & Arabidopsis & 22 & $\begin{array}{l}\text { Hsp90 inhibitors activated the transcription of Hsps and increased } \\
\text { thermotolerance }\end{array}$ & $\begin{array}{l}\text { Yamada et al. } \\
\text { (2007) }\end{array}$ \\
\hline & & 37 & $\begin{array}{l}\text { Hsp90.2 binds HsfA1d in the absence of heat; heat treatment inhibited } \\
\text { Hsp90 activity }\end{array}$ & \\
\hline \multirow[t]{2}{*}{ Hsp90 inhibition } & Physcomitrella & 37 & $\begin{array}{l}\text { ROF1-Hsp90 complex translocates to the nucleus by heat via interaction } \\
\text { with HsfA2 }\end{array}$ & $\begin{array}{l}\text { Meiri and } \\
\text { Breiman (2009) }\end{array}$ \\
\hline & & 22 & Hsp90 inhibitors induced a $\mathrm{Ca}^{2+}$-dependent HSR & Saidi et al. (2009) \\
\hline
\end{tabular}

\subsubsection{Reactive Oxygen Species}

ROS and its reaction products are the most significant second messengers that actively participate in stress signal transduction (Gong et al., 2013; Chakradhar et al., 2017; Khan and Khan, 2017). ROS have been credibly evidenced to play a significant role in signaling, redox-sensing mechanisms, and plant survival under abiotic stresses (Mittler, 2002; Mittler et al., 2004, 2008, 2010; Gill and Tuteja, 2010). A number of researchers have considered $\mathrm{H}_{2} \mathrm{O}_{2}$ as an active signaling molecule in plants, where a variety of cellular responses are accomplished due to redox-sensingmediated $\mathrm{H}_{2} \mathrm{O}_{2}$ accumulation (Bhattacharjee, 2005; Del Rio and Velez-Pardo, 2006; Halliwell, 2006; Kovalchuk, 2010; Ashfaque et al., 2014; Khan et al., 2016). Though little information is available on ROS-mediated induction of the redox-sensing mechanisms and the associated signaling pathways, the contribution of ROS-induced signaling in the activation of defense genes and subsequent stress tolerance/specific acclamatory responses has been widely accepted (Aslund et al., 1999; Goyer et al., 2002; Locato et al., 2009). Researchers provided the clues in support of $\mathrm{H}_{2} \mathrm{O}_{2}$ as a central metabolite and diffusible signal that has the capacity to induce a number of defense related genes (Chen et al., 1993; Prasad et al., 1994). Chloroplastic ROS contributing to the signaling cascade of the $\mathrm{Hsp}$ genes were not affected by apoplastic $\mathrm{H}_{2} \mathrm{O}_{2}$ or $\mathrm{H}_{2} \mathrm{O}_{2}$ produced by the plasma membrane (Scarpeci et al., 2008). Increase in temperature would enhance the mitochondrial production of ROS in plant cells (Pucciariello et al., 2012; Suzuki et al., 2012; Kreslavski et al., 2012). An increase in $\mathrm{mt} \Delta \psi$ (potential difference across the inner mitochondrial membrane) (Rikhvanov et al., 2007; Pyatrikas et al., 2014; Pavlova et al., 2009; Pulyaevskaya et al., 2011) and ROS production (Saidi et al., 2011;Volkov et al., 2006; Miller and Mittler, 2006) is essential for the activation of Hsp expression under heat stress. Inhibitors and uncouplers of mitochondria suppress the increase in $\mathrm{mt} \Delta \psi$ and inhibit the activation of the Hsp expression at elevated temperatures, even though these agents sometimes activate Hsp expression in the absence of heat stress (Rikhvanov et al., 2007; Pyatrikas et al., 2014). Likely, the addition of antioxidants inhibits Hsp expression under heat stress (Volkov et al., 2006; Saidi et al., 2011; Mittler et al., 2012). Production of ROS under heat stress is probably associated with changes in $\left[\mathrm{Ca}^{2+}\right]$ cyt and with hyperpolarization of the mitochondrial membrane. On the other hand, the rate of ROS generation in mammalian mitochondria is known to enhance with an increase in $\mathrm{mt} \Delta \psi$ (Korshunov et al., 1997). Similar concepts can be applied to plant cells. The increase in $\mathrm{mt} \Delta \psi$ induced by extracellular ATP (Sun et al., 2012) and camptothecin (Weir et al., 2003) stimulated ROS production, whereas the protonophore CCCP known to diminish $\mathrm{mt} \Delta \psi$ inhibited this process. Hence, $\mathrm{mt} \Delta \psi$ level can be among the factors determining ROS formation under heat stress. Apparently, plant cell mitochondria participate in the regulation of Hsp expression by controlling not only the $\left[\mathrm{Ca}^{2+}\right]$ cyt level but also ROS generation. This also shows the crosstalk between different signaling pathways in the regulation of Hsps.

\subsubsection{Mitogen Activated Protein Kinases}

Mitogen activated protein kinases (MAPKs) are the best-studied plant protein kinases that connect different receptors/sensors to cellular and nuclear responses (Tena et al., 2001; Sinha et al., 2011). The MAP kinase pathways facilitate signal transduction from the surface of the cell to the nucleus and are extensively used as osmolarity signaling modules. The environmental 
signals are initially perceived by specific receptors, which on being activated initiate a cascade to transmit the signal intracellularly and activate nuclear TFs to induce expression of specific target genes. Evidence shows that plants quickly activate MAPK when exposed to multiple abiotic stress stimuli (Kiegerl et al., 2000; Ligterink and Hirt, 2001). MAPKs are dual function kinases that are stimulated through phosphorylation of their two amino acids in sequential order, starting from the MAPK kinase kinase (MAPKKK) to MAPK kinase (MAPKK) to MAPK (Fig. 32.2). A series of subfamilies (i.e., MAP4K, MAP3K, MAP2K, MAPK) are chronologically activated in this MAPK cascade as a result of various environmental stimuli that in turn activate TFs like Hsf, phospholipases, or microtubuleassociated proteins, and the expression of Hsps (Wang et al., 2003; Sasabe et al., 2006) (Fig. 32.2). MAPK modules in plant tolerance to abiotic stress is illustrated, in which a tobacco MAPKKK ANP orthologue, NPK1, was expressed in an active form in Arabidopsis thaliana. NPK1 mediates $\mathrm{H}_{2} \mathrm{O}_{2}$ regulated gene expression in plants (Kovtun et al., 2000). In Arabidopsis, MAPK6 targets AtHsfA2, phosphorylates it on T249, and changes its intracellular localization under HS conditions (Evrard et al., 2013). AtHsfA4A interacts with the MAP kinases MPK3 and MPK6 and is phosphorylated in vitro on three distinct sites, with Ser-309 being the major phosphorylation site (Pérez-Salamó et al., 2014).
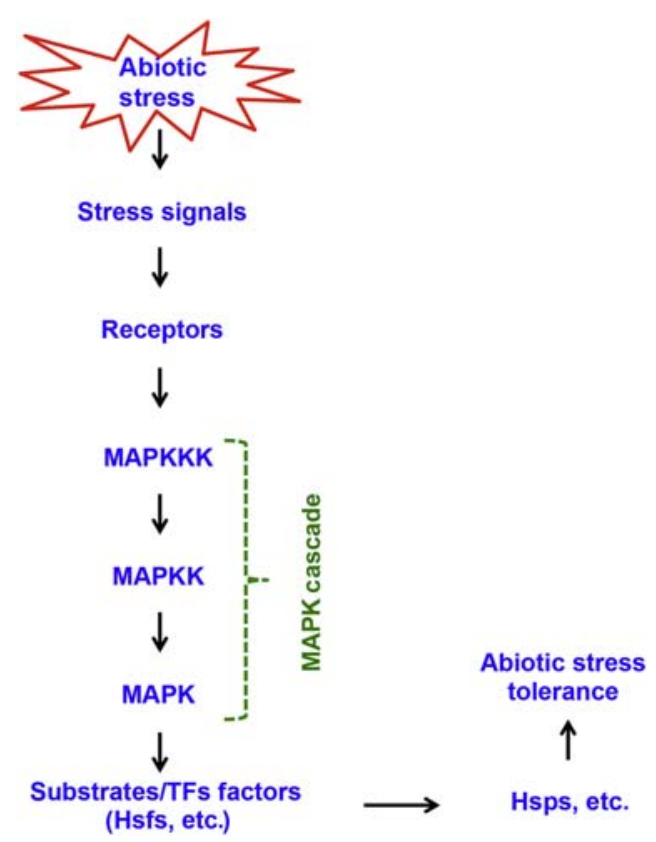

FIGURE 32.2 Predicted model of MAP kinase cascade pathway represents the cascade mechanism of MAPK phosphorylation system that serves as a link between receptors, stress signals, and downstream signaling components such as TFs to activate genes and induce abiotic stress tolerance.
Nishizawa-Yokoi et al. (2010) described that AtHsfA2 was regulated by the accumulation of polyubiquitinated proteins generated by the inhibition of $26 \mathrm{~S}$ proteasome and AtHsp90.

\subsubsection{Calcium and Calcium-Regulated Proteins}

In plants, $\mathrm{Ca}^{2+}$ serves as an important, ubiquitous second messenger and regulates many physiological processes (Tuteja and Sopory, 2008; Tuteja, 2009; Boudsocq et al., 2010). $\mathrm{Ca}^{2+}$ channels, pumps, and exchangers (carriers) control the plant $\mathrm{Ca}^{2+}$ homeostasis maintenance under a variety of stimuli through the regulation of diverse $\mathrm{Ca}^{2+}$ transport systems (Gong et al., 2013; Boudsocq et al., 2010; Kudla et al., 2010). In addition, reduction in $\mathrm{Ca}^{2+}$ mobility, localization, and spatial concentration elevations are facilitated by the abundance of buffering $\mathrm{Ca}^{2+}$ sensors (Dodd et al., 2010). $\mathrm{Ca}^{2+}$ sensor groups, namely, sensor relays [calmodulin (CaMs), calcineurin B-like (CBL)], and sensor responders, that is, sensor protein kinases [CDPKs, calcium and calmodulindependent protein kinases (CCaMKs)] lack any intrinsic enzymatic activity, directly activated upon $\mathrm{Ca}^{2+}$ binding, decode cellular $\mathrm{Ca}^{2+}$ signals, and transmit the $\mathrm{Ca}^{2+}$ induced modification to target proteins (Fig. 32.3).

Activation and inactivation of Hsf are determined by the degree of its phosphorylation and dephosphorylation, because of which it should be clear that $\mathrm{Ca}^{2+}$ activates Hsf indirectly, by modulating the activity of protein kinases and phosphatases (Voellmy and Boellmann, 2007). Serine residue phosphorylation at position 230 leads to transcriptional activity of a human Hsf1. This process is carried out by $\mathrm{Ca}^{2+} / \mathrm{CaM}$ dependent kinase II (CaMK II) (Holmberg et al., 2001). It is evident that $\mathrm{Ca}^{2+} / \mathrm{CaM}$ binding protein kinases $(\mathrm{CBK})$ and $\mathrm{Ca}^{2+}$ dependent protein kinases (CPK) in plants perform a similar function (Fig. 32.3). It is seen that CBK3 phosphorylated HsfA1a (Liu et al., 2008), while CPK3 and CPK13 phosphorylated HsfB2a (Kanchiswamy et al., 2010a; Kanchiswamy et al., 2010b), which activated Hsp expression in heat stressed $A$. thaliana. MAP kinase (HAMK), which is activated by heat, may also be involved in Hsf phosphorylation. HAMK was shown to be a $\mathrm{Ca}^{2+}$ dependent kinase and activated under heat stress in cultured tobacco cells, which is necessary for the expression of Hsp70 (Suri and Dhindsa, 2008). Dephosphorylation of certain serine residues in Hsf also leads to its activation. In A. thaliana dephosphorylation is performed by serine/threonine phosphatase PP7. It was shown that PP7 interacts with both CaM and Hsf. A mutation in PP7 gene inhibited the expression of Hsps under heat stress (Liu et al., 2007). It is not excluded that the ability of Hsp70 and Hsp90 to regulate Hsf activity 

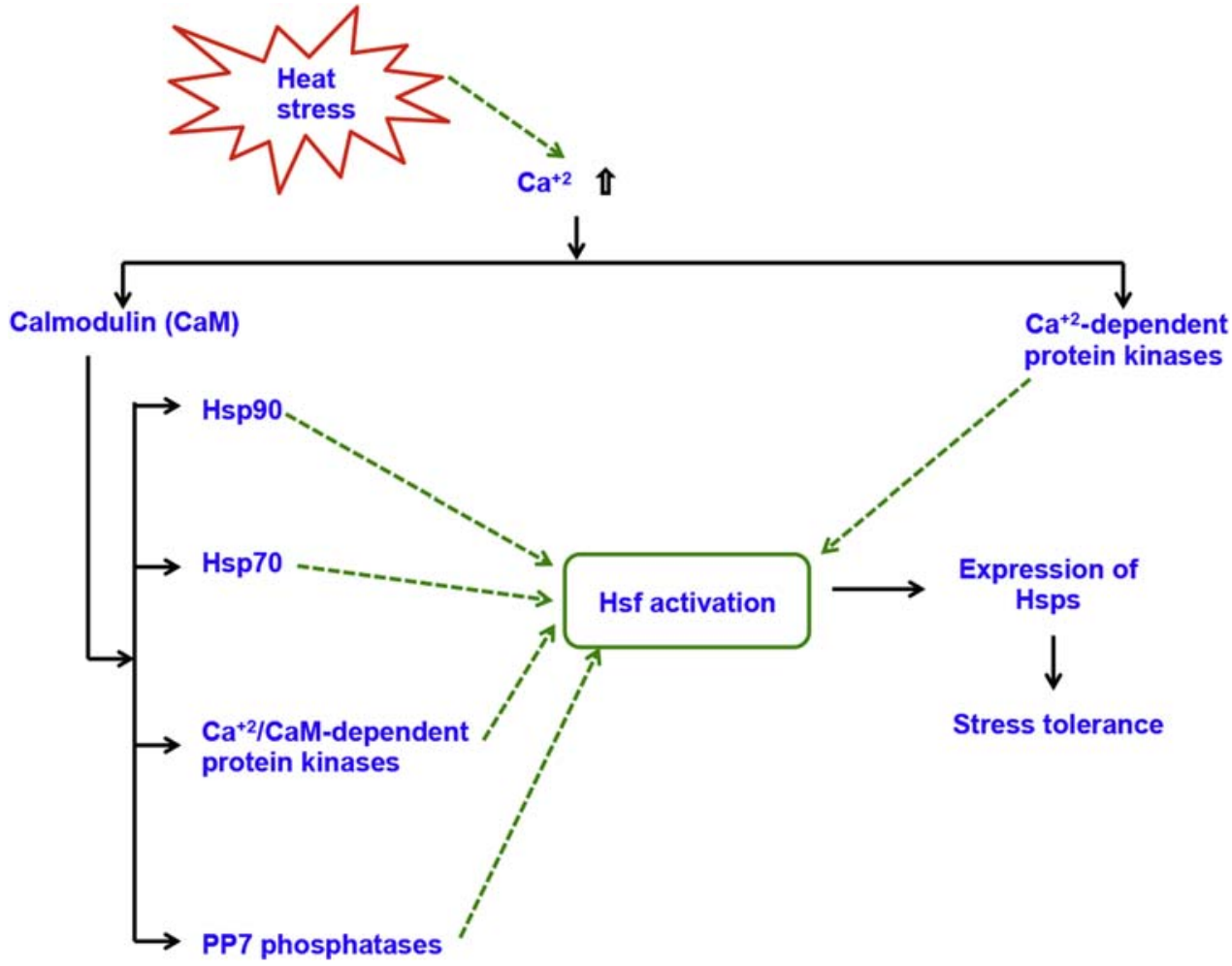

FIGURE 32.3 Mechanism depicting Ca-dependent activation of Hsf and Hsps in heat stressed plants.

depends on $\left[\mathrm{Ca}^{2+}\right]$ cyt. As seen, Hsp70 contains the CaM binding site (Sun et al., 2000). Although Hsp90 is devoid of such site, its activity can be modulated by adapter proteins possessing the CaM binding site (Meiri and Breiman, 2009; Saidi et al., 2011; Mittler et al., 2012). Activation of Hsps through calcium ion in heat stress conditions sustains the plants in heat stress conditions (Fig. 32.3).

\subsection{CROSSTALK BETWEEN REACTIVE OXYGEN SPECIES, MITOGEN ACTIVATED PROTEIN KINASES CASCADES, $\mathrm{CA}^{+2}$ AND HEAT SHOCK FACTOR/HEAT SHOCK PROTEINS}

Abiotic stresses are perceived by different signaling mechanisms, among which few are specific, and some may have crosstalk at different stages. Intricate teamwork and interaction of signaling mechanism is adopted by abiotic-stressed plants to perceive transducer stress signals and finally to transduce stress responses. ROS, TFs, $\mathrm{Ca}^{2+}$ and $\mathrm{Ca}^{2+}$-regulated proteins, and MAPK cascades are credibly being evidenced to sport a significant role in plant abiotic stress signaling cascades. Induction of changes in $\mathrm{Ca}^{2+}$ in the cytosol is observed with hormonal signals (Poovaiah et al., 1993). The initiation of MAPK in plants has also been reported to be evoked by $\mathrm{H}_{2} \mathrm{O}_{2}$ (Desikan et al., 2001; Grant et al., 2000; Neill et al., 2002; Song et al., 2008; Palavan-Unsal and Arisan, 2009). Involvement of $\mathrm{Ca}^{2+}$-dependent MAPK pathways in signaling of abiotic stress in plant cells is also known (Wurzinger et al., 2011). However, although much has been attained in the area of plant abiotic stress signaling pathways, efforts should be made with the assistance of powerful molecular tools, including transcriptome and proteome analysis, to understand more about molecular mechanism(s) underlying $\mathrm{ROS}$ and $\mathrm{Ca}^{2+}$ sensing and signal transduction.

Hsp as well as Hsfs are the most important factors in crosstalk between various stress signaling transduction networks as understood through the comparative study of global expression profiling in heat, salt, and drought stresses in rice seedlings ( $\mathrm{Hu}$ et al., 2009). A number of recent studies have shown proofs in context to interrelations among Hsfs, Hsps, ROS, and ROS scavengers under heat stress conditions. To activate Hsfs directly, elevated temperatures enhance the accumulation of ROS, which again activates Hsfs, either straight away or indirectly through triggering the MAPK pathway. The Hsfs tend to bind to HSE in the 5 upstream region of different genes like Hsf, Hsp, miRNA398, and ROS scavenging genes. The miRNA398-dependent repression of SOD scavengers may have a role in the quick ROS accumulation upon exposure to heat. 
This supports the triggering of Hsfs, which then boosts induction of the heat stress response in a lower duration. sHsp protein plays a crucial part in safeguarding PSII and PSI during chilling stress in low illumination in tobacco (Guo et al., 2007). These findings suggest that Hsps are not active only in heat stress, but are also active in other stresses by activating a cascade of signaling reactions. In the longer term, the induction and stabilization of other scavengers would start to suppress ROS levels to avoid excessive cellular damage.

\subsection{GENETIC ENGINEERING OF HEAT SHOCK PROTEINS SIGNALING MOLECULES}

Different approaches have been made to produce stress resistant plants for tackling global warming. The molecular mechanism of abiotic stress tolerance depends on activation and modulation of genes that are related to specific stress conditions. Abiotic stress sustenance in plants can be achieved by the combination of molecular and traditional plant breeding (Wang et al., 2003; Vinocur and Altman, 2005) and alternatively through forward and reverse genetic approaches (Lavania et al., 2015; Driedonks et al., 2015; Usman et al., 2014; Reddy et al., 2016). There is much evidence that shows that a broad conservation of the Hsp/ chaperone web as a multiple stress defense mechanism admits all land plants. Indeed, plant alteration was shown to be strongly dependent on Hsps as shown from the diversification of the Hsp families. Proteomic and genomic studies have also revealed a positive correlation between the expression of Hsps and tolerance to different abiotic stress conditions. Transgenic plants that are overexpressing either of Hsps or Hsfs possess enhanced antioxidant activities, higher osmolyte levels, and higher expression of the stress inducible genes, which is indicative of the activation of different stressresponsive mechanisms by Hsps and their role in the cross stress tolerance of the plants ( $\mathrm{Li}$ et al., 2012; Lee et al., 2012; Zhou et al., 2012b; Zou et al., 2012; Mu et al., 2013; Song et al., 2014; Wang et al., 2015; Masand and Yadav, 2016; Wan et al., 2016). Overexpression and knockout studies showed Hsp70 plays a protective role during dehydration stress in tobacco, soybean, and citrus (Yu et al., 2015). OsAhl1 of rice was shown to directly induce Hsp101 and Hsp90 expression leading to drought resistance (Zhou et al., 2016). OsHsp90-2 and OsHsp90-4 were also seen to be upregulated under drought, cold, heat, and salt stresses (Zhang et al., 2016). OsHsp90-2, when introduced in E. coli, was sufficient to induce resistance to heat, huge salinity conditions, and drought (Reddy et al., 2011; Zhang et al., 2016). Similar regulations of these Hsfs and Hsps were seen in tomato in stimuli to heat, drought, and salinity (Fragkostefanakis et al., 2015). In wheat, overexpression of Triticum HsfA6f was demonstrated to direct the expression of several Hsps, leading to thermotolerance (Xue et al., 2014). Increased expression of soybean GmHsp90s decreases the destruction of abiotic stresses in Arabidopsis thaliana ( $\mathrm{Xu}$ et al., 2013). The expression of $\mathrm{ZmHsf06}$ (Zea mays) is sufficient to confer heat and drought stress resistance in Arabidopsis. Identification of Hsf signaling from monocots to dicots definitely shows an intense preservation of Hsp-based multiple stress responses in crops.

Hsps repair the structure of the protein and the target at incorrectly aggregated and nonnative proteins for removing it out of the cells (Cho and Hong, 2006). It was found that both the overexpression of Hsc70 and the use of a dominant negative $(\mathrm{DN})$ form of Hsp90 disrupted ABA-mediated stomata closure, thereby negatively affecting water loss in stress conditions. The targets of Hsp90 and Hsc70 are not known yet, but must be downstream of SnRK2 as it was fully activated after ABA treatment, despite the use of an Hsp90 inhibitor (Clément et al., 2011). NtHsp70-1 is one among such proteins, which is constitutively overexpressed in tobacco to find out its role in plant drought response and tolerance. The tolerance of transgenic seedlings to drought was enhanced and their optimum water content was sustained after drought stress (Cho and Hong, 2006). Hsp24 from Trichederma was seen to develop significantly higher resistance to salt, drought, and heat stress in yeast (Liming et al., 2008). Expression of the CaHsp26 gene in transgenic tobacco showed that the mRNA accumulation of CaHsp26 was triggered by heat stress (Guo et al., 2007). Overexpression of soybean GmHsfA1 can increase the thermotolerance of transgenic soybeans because of the activation under HS of downstream genes, such as GmHsp70, GmHsp22, and other GmHsps (Zhu et al., 2006). HsfA2 has been identified to be the dominant Hsf in tomato and Arabidopsis based on its high activator potential for transcription of $H s p$ genes and the strong accumulation under conditions of long-term HS or repeated cycles of HS and recovery (Mishra et al., 2002; von Koskull-Döring et al., 2007). Studies on tomato HsfB1 with a variant of lysine residue that was replaced by its Arabidopsis counterpart showed that $H s f B 1$ and $H s f B 2 b$ may promote the activity of $H s f A 1$ under HS conditions by repressing Hsps that interfere with the nuclear migration of HsfA1s, an activator of the early HS response (Ikeda et al., 2011). In Arabidopsis, overexpression of RcHsp17.8 enhanced the SOD activity (Jiang et al., 2009) whereas overexpression of ZmHSP16.9 in tobacco enhanced POD, CAT, and SOD activity (Sun et al., 2012). Overexpression of the LeCDJ1 DnaJ protein-coding gene also known as 
J-protein or Hsp40 (Qiu et al., 2006) in tomato resulted in improved thermotolerance, accompanied by increased Apx and SOD activity after heat stress and reduced accumulation of $\mathrm{O}_{2}{ }^{-}$and $\mathrm{H}_{2} \mathrm{O}_{2}$. Also, tomato plants overexpressing the DnaJ/Hsp40 LeCDJ1 showed both higher heat and chilling tolerance (Kong et al., 2013, 2014a) and overexpression of BRZ-INSENSITIVE-LONG HYPOCOTYLS 2 (BIL2), a mitochondrial-localized DnaJ/Hsp40 family member, enhanced resistance against salinity and high light stress (Bekh-Ochir et al., 2013). Zhang et al. (2009) could demonstrate that AtCaM3 knockout mutant plants in Arabidopsis were more sensitive to heat stress, whereas high expression of CaM3 showed enhanced thermotolerance. Moreover, CaM3 is supposed to be involved in the activation of Hsfs shown by electrophoretic mobility-shift assays, real-time quantitative reverse transcription-polymerase chain reaction, and Western-blot analyses (Zhang et al., 2009). HsfA3 helps in DREB2A signaling inducing the expression of Hsfs (Schramm et al., 2008; Yoshida et al., 2008). The multiprotein bridging factor1c (MBF1c) modulates several genes, including $D R E B 2 A$ and two classes of B Hsfs. MBF1c overexpression in plants revealed increased tolerance to heat, osmotic, and biotic stress (Bechtold et al., 2010; Suzuki et al., 2005, 2011).

Overexpression of Hsf3 in Arabidopsis has shown enhanced functionality of $A p x$ at the time of postheatstress recovery and expressed solid induction of $A p x 2$ in comparison with the wild-type Arabidopsis (Panchuk et al., 2002). In a knockout Apx1, crops accumulated $\mathrm{H}_{2} \mathrm{O}_{2}$ in mild light stress in which $H s f 21$ was seen to be increased in light stress initial stages (Davletova et al., 2005a, Pnueli et al., 2003). When wild-type cells are put on with $\mathrm{H}_{2} \mathrm{O}_{2}$, accumulation of transcripts that encode for Hsf21 are seen to be aggregated (Davletova et al., 2005b). A variant of $H s f 21$ showed reduced expression of Zat12, which is a $\mathrm{H}_{2} \mathrm{O}_{2}$-responsive zinc finger protein wanted for expression of Apx1 in transgenic plants (Davletova et al., 2005a). From these studies, the critical function of Hsfs in initial sensing of $\mathrm{H}_{2} \mathrm{O}_{2}$ and Apx1, Apx2, and Zat12 expression is revealed.

\subsection{CONCLUSIONS AND FUTURE PERSPECTIVES}

The ubiquitous role of Hsps is seen in stabilization of proteins and maintaining the homeostasis in the cell. Heat stress muddles cellular homeostasis, which leads to developmental aberrations, growth retardation, and eventually plant death in some cases. Heat stress acts initially upon the quaternary structure of the folding protein, activity of which is lost due to exposure to elevated temperatures, which have deleterious effects on plant metabolism. This results in the removal of connections between the signaling pathways. In this context, further elucidation is required to understand how plants better respond to heat and other major abiotic stresses from the physiological and molecular perspectives. Still, we need to understand precisely how Hsps/chaperones participate in sensing, translocation of immune receptors, signal transduction, and transcriptional activation of several stress genes. Hence, first what needs to be focused upon is understanding the way plants respond to heat stress and utilizing this knowledge in the development of thermotolerant crops.

Many abiotic stress signaling components have been identified from mutants or functional genomic studies. Still, there is only a fragmentary view of understanding the abiotic stress signaling pathways. Functional genomics approaches by forward and reverse genetics will continue to be imperative to break through these complex pathways. Conventional genetic screens have yielded immensely important insight into stress signal transduction; this approach may ultimately be limited due to functional redundancy of components within the signaling pathways. Molecular screens based on reporter genes are a better way to identify upstream signaling components that control subsets of responses that may not manifest as visible tolerance phenotypes. Detailed characterization of mutant phenotypes will provide an indication if a signaling component function is in a specific pathway or is involved in multiple pathways. Analysis of spatial and temporal expression patterns, in combination with biochemical analysis, will be required to firmly establish specificity or crosstalk of the signaling mechanisms and their pathways.

More elucidation is required to explore opportunities to better understand how plants respond to major abiotic stresses and their cross connectivity. Multiple genes affected under abiotic stresses imply that there could not be a single marker for protection against stress. There is a lot of crosstalk taking place between various hormonal pathways, and the exact nature of this crosstalk during simultaneous biotic and abiotic stress is yet to be investigated. Researchers should look forward for defined set of markers to predict tolerance towards a particular stress with a definite degree of affirmation. Though much has been achieved in the context of plant abiotic stress signaling pathways, efforts should be made with the aid of powerful modern molecular tools, including transcriptomic and proteomics technologies, to get more insights into molecular mechanism(s) underlying various signaling cascades, that is, ROS and $\mathrm{Ca}^{2+}$ sensing signal transduction pathways. Mutations or edits enhancing Hsf/ Hsps expression or activity undoubtedly are valuable targets to engineer multi-stress resistant crops through 
recently discovered CRISPR/Cas9 (clustered regularly interspaced short palindromic repeat-CRISPR associated 9) system and TILLING (targeted induced local lesion in genomes), which would allow a rapid technology transfer in crops.

\section{Acknowledgments}

PSR acknowledges the Department of Science and Technology, Govt. of India for the fellowship and research grant through the INSPIRE Faculty Award No. IFALSPA-06. This work was undertaken as part of the CGIAR Research Program on Dry land Cereals.

\section{References}

AbouQamar, S., Luo, H., Laluk, K., Mickelbart, M.V., Mengiste, T., 2009. Crosstalk between biotic and abiotic stress responses in tomato is mediated by the AIM1 transcription factor. Plant J. 58 (2), 347-360.

Agarwal, M., Katiyar-Agarwal, S., Sahi, C., Gallie, D.R., Grover, A., 2001. Arabidopsis thaliana Hsp100 proteins: kith and kin. Cell Stress Chap. 6 (3), 219-224.

Akpinar, B.A., Avsar, B., Lucas, S.J., Budak, H., 2012. Plant abiotic stress signalling. Plant Signal. Behav. 7 (11), 1450-1455.

Al-Whaibi, M.H., 2011. Plant heat-shock proteins: a mini review. J. King Saud Univ. Sci. 23 (2), 139-150.

Andreasson, E., Ellis, B., 2010. Convergence and specificity in the Arabidopsis MAPK nexus. Trends. Plant. Sci. 15 (2), 106-113.

Apuya, N.R., Yadegari, R., Fischer, R.L., Harada, J.J., Zimmerman, J. L., Goldberg, R.B., 2001. The Arabidopsis embryo mutant schlepperless has a defect in the chaperonin- $60 \alpha$ gene. Plant Physiol. 126 (2), 717-730.

Åslund, F., Zheng, M., Beckwith, J., Storz, G., 1999. Regulation of the OxyR transcription factor by hydrogen peroxide and the cellular thiol-disulfide status. Proc. Natl. Acad. Sci. 96 (11), 6161-6165.

Ashfaque, F., Khan, M.I.R., Khan, N.A., 2014. Exogenously applied $\mathrm{H} 2 \mathrm{O} 2$ promotes proline accumulation, water relations, photosynthetic efficiency and growth of wheat (Triticum aestivum L.) under salt stress. Annu. Res. Rev. Biol. 4, 105-120.

Aviezer-Hagai, K., Skovorodnikova, J., Galigniana, M., FarchiPisanty, O., Maayan, E., Bocovza, S., et al., 2007. Arabidopsis immunophilins ROF1 (AtFKBP62) and ROF2 (AtFKBP65) exhibit tissue specificity, are heat-stress induced, and bind HSP90. Plant Mol. Biol. 63 (2), 237-255.

Baniwal, S.K., Bharti, K., Chan, K.Y., Fauth, M., Ganguli, A., Kotak, S., et al., 2004. Heat stress response in plants: a complex game with chaperones and more than twenty heat stress transcription factors. J. Biosci. 29 (4), 471-487.

Banti, V., Mafessoni, F., Loreti, E., Alpi, A., Perata, P., 2010. The heatinducible transcription factor HsfA2 enhances anoxia tolerance in Arabidopsis. Plant Physiol. 152, 1471-1483.

Bartels, D., Phillips, J., Chandler, J., 2007. Desiccation tolerance: gene expression, pathways, and regulation of gene expression. Plant Desiccat. Toler. 35, 115-137.

Basu, S., Roychoudhury, A., 2014. Expression profiling of abiotic stress-inducible genes in response to multiple stresses in rice (Oryza sativa L.) varieties with contrasting level of stress tolerance. Biomed. Res. Int. 2014.

Bechtold, U., Lawson, T., MEJIA-CARRANZA, J.A.I.M.E., Meyer, R. C., Brown, I.R., Altmann, T., et al., 2010. Constitutive salicylic acid defences do not compromise seed yield, drought tolerance and water productivity in the Arabidopsis accession C24. Plant Cell Environ. 33 (11), 1959-1973.

Bekh-Ochir, D., Shimada, S., Yamagami, A., Kanda, S., Ogawa, K., Nakazawa, M., et al., 2013. A novel mitochondrial DnaJ/Hsp40 family protein BIL2 promotes plant growth and resistance against environmental stress in brassinosteroid signaling. Planta 237 (6), 1509-1525.

Bhattacharjee, S., 2005. Reactive oxygen species and oxidative burst: roles in stress, senescence and signal transduction in plants. Curr. Sci. 1113-1121.

Boguszewska, D., Zagdańska, B., 2012. ROS as signalling molecules and enzymes of plant response to unfavorable environmental conditions. Oxidative Stress-Molecular Mechanisms and Biological Effects. InTech, Rijeka, Croatia, pp. 341-362.

Bösl, B., Grimminger, V., Walter, S., 2006. The molecular chaperone Hsp104-a molecular machine for protein disaggregation. J. Struct. Biol. 156 (1), 139-148.

Boudsocq, M., Willmann, M.R., McCormack, M., Lee, H., Shan, L., $\mathrm{He}, \mathrm{P}$. , et al., 2010. Differential innate immune signalling via Ca $2+$ sensor protein kinases. Nature 464 (7287), 418.

Bukau, B., Horwich, A.L., 1998. The Hsp70 and Hsp60 chaperone machines. Cell 92 (3), 351-366.

Chakradhar, T., Mahanty, S., Reddy, R.A., Divya, K., Reddy, P.S., Reddy, M.K., 2017. Biotechnological perspective of reactive oxygen species (ROS)-mediated stress tolerance in plants. Reactive Oxygen Species and Antioxidant Systems in Plants: Role and Regulation under Abiotic Stress. Springer, Singapore, pp. 53-87.

Charng, Y.Y., Liu, H.C., Liu, N.Y., Chi, W.T., Wang, C.N., Chang, S. H., et al., 2007. A heat-inducible transcription factor, HsfA2, is required for extension of acquired thermotolerance in Arabidopsis. Plant Physiol. 143 (1), 251-262.

Chen, Z., Silva, H., Klessig, D.F., 1993. Active oxygen species in the induction of plant systemic acquired resistance by salicylic acid. Science 262 (5141), 1883-1886.

Chinnusamy, V., Schumaker, K., Zhu, J.K., 2004. Molecular genetic perspectives on cross-talk and specificity in abiotic stress signalling in plants. J. Exp. Bot. 55 (395), 225-236.

Cho, E.K., Hong, C.B., 2006. Over-expression of tobacco NtHSP70-1 contributes to drought-stress tolerance in plants. Plant Cell Rep. 25 (4), 349-358.

Clément, M., Leonhardt, N., Droillard, M.J., Reiter, I., Montillet, J.L., Genty, B., et al., 2011. The cytosolic/nuclear HSC70 and HSP90 molecular chaperones are important for stomatal closure and modulate abscisic acid-dependent physiological responses in Arabidopsis. Plant Physiol. 156 (3), 1481-1492.

Cronjé, M.J., Weir, I.E., Bornman, L., 2004. Salicylic acid-mediated potentiation of Hsp70 induction correlates with reduced apoptosis in tobacco protoplasts. Cytom. Part A 61 (1), 76-87.

Davletova, S., Schlauch, K., Coutu, J., Mittler, R., 2005a. The zincfinger protein Zat12 plays a central role in reactive oxygen and abiotic stress signaling in Arabidopsis. Plant Physiol. 139 (2), $847-856$

Davletova, S., Rizhsky, L., Liang, H., Shengqiang, Z., Oliver, D.J., Coutu, J., et al., 2005b. Cytosolic ascorbate peroxidase 1 is a central component of the reactive oxygen gene network of Arabidopsis. Plant Cell 17 (1), 268-281.

Del Rio, M.J., Velez-Pardo, C., 2006. Insulin-like growth factor-1 prevents $\mathrm{Ab}[25-35] /(\mathrm{H} 2 \mathrm{O} 2)$-induced apoptosis in lymphocytes by reciprocal NF-kB activation and p53 inhibition via PI3Kdependent pathway. Growth Factors 24 (1), 67-78.

Desikan, R., Hancock, J.T., Ichimura, K., Shinozaki, K., Neill, S.J., 2001. Harpin Induces Activation of the Arabidopsis MitogenActivated Protein Kinases AtMPK4 and AtMPK6. Plant Physiol. 126 (4), 1579-1587. 
Díaz-Villanueva, J.F., Díaz-Molina, R., García-González, V., 2015. Protein folding and mechanisms of proteostasis. Int. J. Mol. Sci. 16 (8), 17193-17230.

Dodd, A.N., Kudla, J., Sanders, D., 2010. The language of calcium signalling. Annu. Rev. Plant. Biol. 61, 593-620.

Downs, C.A., Heckathorn, S.A., 1998. The mitochondrial small heatshock protein protects NADH: ubiquinone oxidoreductase of the electron transport chain during heat stress in plants. FEBS Lett. 430 (3), 246-250.

Driedonks, N., Xu, J., Peters, J.L., Park, S., Rieu, I., 2015. Multi-level interactions between heat shock factors, heat shock proteins, and the redox system regulate acclimation to heat. Front. Plant Sci. 6, 999.

Evrard, A., Kumar, M., Lecourieux, D., Lucks, J., von KoskullDöring, P., Hirt, H., 2013. Regulation of the heat stress response in Arabidopsis by MPK6-targeted phosphorylation of the heat stress factor HsfA2. PeerJ 1, e59.

Floto, R.A., MacAry, P.A., Boname, J.M., Mien, T.S., Kampmann, B., Hair, J.R., et al., 2006. Dendritic cell stimulation by mycobacterial Hsp70 is mediated through CCR5. Science 314 (5798), 454-458.

Fragkostefanakis, S., Simm, S., Paul, P., Bublak, D., Scharf, K.D., Schleiff, E., 2015. Chaperone network composition in Solanum lycopersicum explored by transcriptome profiling and microarray meta-analysis. Plant Cell Environ. 38 (4), 693-709.

Gill, S.S., Tuteja, N., 2010. Reactive oxygen species and antioxidant machinery in abiotic stress tolerance in crop plants. Plant. Physiol. Biochem. 48 (12), 909-930.

Gong, P., Xu, X., Shi, J., Ni, L., Huang, Q., Xia, L., et al., 2013. Phosphorylation of mitogen-and stress-activated protein kinase-1 in astrocytic inflammation: a possible role in inhibiting production of inflammatory cytokines. PLoS ONE 8 (12), e81747.

Gould, K.S., Lamotte, O., Klinguer, A., Pugin, A., Wendehenne, D., 2003. Nitric oxide production in tobacco leaf cells: a generalized stress response? Plant Cell Environ. 26 (11), 1851-1862.

Goyer, A., Haslekås, C., Miginiac-Maslow, M., Klein, U., Le Marechal, P., Jacquot, J.P., et al., 2002. Isolation and characterization of a thioredoxin-dependent peroxidase from Chlamydomonas reinhardtii. FEBS. J. 269 (1), 272-282.

Grant, M., Brown, I., Adams, S., Knight, M., Ainslie, A., Mansfield, J., 2000. The RPM1 plant disease resistance gene facilitates a rapid and sustained increase in cytosolic calcium that is necessary for the oxidative burst and hypersensitive cell death. Plant J. 23 (4), $441-450$.

Guan, J.C., Yeh, C.H., Lin, Y.P., Ke, Y.T., Chen, M.T., You, J.W., et al., 2010. A 9 bp cis-element in the promoters of class I small heat shock protein genes on chromosome 3 in rice mediates Lazetidine-2-carboxylic acid and heat shock responses. J. Exp. Bot. 61, 4249-4261.

Guo, S.J., Zhou, H.Y., Zhang, X.S., Li, X.G., Meng, Q.W., 2007. Overexpression of CaHSP26 in transgenic tobacco alleviates photoinhibition of PSII and PSI during chilling stress under low irradiance. J. Plant. Physiol. 164 (2), 126-136.

Gupta, S.C., Sharma, A., Mishra, M., Mishra, R.K., Chowdhuri, D.K., 2010. Heat shock proteins in toxicology: how close and how far? Life. Sci. 86 (11-12), 377-384.

Halliwell, B., 2006. Reactive species and antioxidants. Redox biology is a fundamental theme of aerobic life. Plant Physiol. 141 (2), $312-322$.

Hao, H., Naomoto, Y., Bao, X., Watanabe, N., Sakurama, K., Noma, K., et al., 2010. HSP90 and its inhibitors. Oncol. Rep. 23 (6), 1483-1492.

Hartl, F.U., Hayer-Hartl, M., 2002. Molecular chaperones in the cytosol: from nascent chain to folded protein. Science 295 (5561), 1852-1858.

Hendrick, J.P., Hartl, F.U., 1993. Molecular chaperone functions of heat-shock proteins. Annu. Rev. Biochem. 62 (1), 349-384.
Hernandez, L.D., Vierling, E., 1993. Expression of low molecular weight heat-shock proteins under field conditions. Plant Physiol. 101 (4), 1209-1216.

Holmberg, C.I., Hietakangas, V., Mikhailov, A., Rantanen, J.O., Kallio, M., Meinander, A., et al., 2001. Phosphorylation of serine 230 promotes inducible transcriptional activity of heat shock factor 1. EMBO J. 20 (14), 3800-3810.

Hu, W., Hu, G., Han, B., 2009. Genome-wide survey and expression profiling of heat shock proteins and heat shock factors revealed overlapped and stress specific response under abiotic stresses in rice. Plant Sci. 176 (4), 583-590.

Ikeda, M., Mitsuda, N., Ohme-Takagi, M., 2011. Arabidopsis HsfB1 and HsfB2b act as repressors of the expression of heat-inducible Hsfs but positively regulate the acquired thermotolerance. Plant Physiol. 157 (3), 1243-1254.

Jackson-Constan, D., Akita, M., Keegstra, K., 2001. Molecular chaperones involved in chloroplast protein import. Biochimica et Biophysica Acta (BBA)-Mol. Cell Res. 1541 (1-2), 102-113.

Jiang, C., Xu, J., Zhang, H.A.O., Zhang, X., Shi, J., Li, M.I.N., et al., 2009. A cytosolic class I small heat shock protein, RcHSP17. 8, of Rosa chinensis confers resistance to a variety of stresses to Escherichia coli, yeast and Arabidopsis thaliana. Plant Cell Environ. 32 (8), 1046-1059.

Johnson, J.L., Brown, C., 2009. Plasticity of the Hsp90 chaperone machine in divergent eukaryotic organisms. Cell Stress Chap. 14 (1), 83-94.

Kanchiswamy, C.N., Takahashi, H., Quadro, S., Maffei, M.E., Bossi, S., Bertea, C., et al., 2010a. Regulation of Arabidopsis defense responses against Spodoptera littoralis by CPK-mediated calcium signalling. BMC Plant Biol. 10 (1), 97.

Kanchiswamy, C.N., Muroi, A., Maffei, M.E., Yoshioka, H., Sawasaki, T., Arimura, G.I., 2010b. Ca2 +-dependent protein kinases and their substrate HsfB2a are differently involved in the heat response signaling pathway in Arabidopsis. Plant Biotechnol. 27 (5), 469-473.

Khan, M.I.R., Khan, N., 2017. Reactive Oxygen Species and Antioxidant System in Plants: Role and Regulation Under Abiotic Stress. Springer Nature, New York, ISBN: 978-981-10-5254.

Khan, M.I.R., Iqbal, N., Masood, A., Khan, N.A., 2012. Variation in salt tolerance of wheat cultivars: evaluation of the role of glycinebetaine and ethylene. Pedosphere 22, 746-754.

Khan, M.I.R., Asgher, M., Khan, N.A., 2013. Rising temperature in the changing environment: a serious threat to plants. Clim. Change Environ. Sust. 1, 25-36.

Khan, M.I.R., Fatma, M., Per, T.S., Anjum, N.A., Khan, N.A., 2015. Salicylic acid-induced abiotic stress tolerance and underlying mechanisms in plants. Front. Plant Sci. 6, 462.

Khan, M.I.R., Khan, N.A., Masood, A., Per, T.S., Asgher, M., 2016. Hydrogen peroxide alleviates nickel-inhibited photosynthetic responses through increase in use-efficiency of nitrogen and sulfur, and glutathione production in mustard. Front. Plant Sci. 7, 44.

Kiegerl, S., Cardinale, F., Siligan, C., Gross, A., Baudouin, E., Liwosz, A., et al., 2000. SIMKK, a mitogen-activated protein kinase (MAPK) kinase, is a specific activator of the salt stress-induced MAPK, SIMK. Plant Cell 12 (11), 2247-2258.

Kim, H.J., Hwang, N.R., Lee, K.J., 2007. Heat shock responses for understanding diseases of protein denaturation, Molecules \& Cells, 23. Springer Science \& Business Media BV (2).

Knight, H., Knight, M.R., 2001. Abiotic stress signalling pathways: specificity and cross-talk. Trends. Plant. Sci. 6 (6), 262-267.

Kong, F., Deng, Y., Zhou, B., Wang, G., Wang, Y., Meng, Q., 2013. A chloroplast-targeted DnaJ protein contributes to maintenance of photosystem II under chilling stress. J. Exp. Bot. 65 (1), 143-158.

Kong, F., Deng, Y., Wang, G., Wang, J., Liang, X., Meng, Q., 2014a. LeCDJ1, a chloroplast DnaJ protein, facilitates heat tolerance in transgenic tomatoes. J. Integr. Plant Biol. 56 (1), 63-74. 
Königshofer, H., Tromballa, H.W., Löppert, H.G., 2008. Early events in signalling high-temperature stress in tobacco BY2 cells involve alterations in membrane fluidity and enhanced hydrogen peroxide production. Plant Cell Environ. 31 (12), 1771-1780.

Korshunov, S.S., Skulachev, V.P., Starkov, A.A., 1997. High protonic potential actuates a mechanism of production of reactive oxygen species in mitochondria. FEBS Lett. 416 (1), 15-18.

Kotak, S., Larkindale, J., Lee, U., von Koskull-Döring, P., Vierling, E., Scharf, K.D., 2007. Complexity of the heat stress response in plants. Curr. Opin. Plant. Biol. 10 (3), 310-316.

Kovalchuk, I., 2010. Multiple roles of radicals in plants. Reactive Oxygen Species and Antioxidants in Higher Plants. CRC Press, New York, NY, pp. 31-44.

Kovtun, Y., Chiu, W.L., Tena, G., Sheen, J., 2000. Functional analysis of oxidative stress-activated mitogen-activated protein kinase cascade in plants. Proc. Natl. Acad. Sci. 97 (6), 2940-2945.

Kreslavski, V.D., Los, D.A., Allakhverdiev, S.I., Kuznetsov, V.V., 2012. Signalling role of reactive oxygen species in plants under stress. Russian J. Plant Physiol. 59 (2), 141-154.

Krukenberg, K.A., Street, T.O., Lavery, L.A., Agard, D.A., 2011. Conformational dynamics of the molecular chaperone Hsp90. Q. Rev. Biophys. 44 (2), 229-255.

Kudla, J., Batistič, O., Hashimoto, K., 2010. Calcium signals: the lead currency of plant information processing. Plant Cell 22 (3), $541-563$.

Lavania, D., Siddiqui, M.H., Al-Whaibi, M.H., Singh, A.K., Kumar, R., Grover, A., 2015. Genetic approaches for breeding heat stress tolerance in faba bean (Vicia faba L.). Acta Physiol. Plant. 37 (1), 1737.

Lee, K.W., Cha, J.Y., Kim, K.H., Kim, Y.G., Lee, B.H., Lee, S.H., 2012. Overexpression of alfalfa mitochondrial HSP23 in prokaryotic and eukaryotic model systems confers enhanced tolerance to salinity and arsenic stress. Biotechnol. Lett. 34 (1), 167-174.

Li, B., Liu, H.T., Sun, D.Y., Zhou, R.G., 2004. Ca2 + and calmodulin modulate DNA-binding activity of maize heat shock transcription factor in vitro. Plant Cell Physiol. 45, 627-634.

Li, L., Xing, Y., Chang, D., Fang, S., Cui, B., Li, Q., et al., 2016. CaM/ BAG5/Hsc70 signalling complex dynamically regulates leaf senescence. Sci. Rep. 6, 31889.

Li, M., Ji, L., Yang, X., Meng, Q., Guo, S., 2012. The protective mechanisms of CaHSP26 in transgenic tobacco to alleviate photoinhibition of PSII during chilling stress. Plant Cell Rep. 31 (11), 1969-1979.

Ligterink, W., Hirt, H., 2001. Mitogen-activated protein (MAP) kinase pathways in plants: versatile signalling tools. Int. Rev. Cytol. 201, 209-275.

Liming, Y., Qian, Y., Pigang, L., Sen, L., 2008. Expression of the HSP24 gene from Trichoderma harzianum in Saccharomyces cerevisiae. J. Therm. Biol. 33 (1), 1-6.

Lindquist, S., 1986. The heat-shock response. Annu. Rev. Biochem. 55 (1), 1151-1191.

Liu, H.T., Li, B., Shang, Z.L., Li, X.Z., Mu, R.L., Sun, D.Y., et al., 2003. Calmodulin is involved in heat shock signal transduction in wheat. Plant Physiol. 132 (3), 1186-1195.

Liu, H.T., Li, G.L., Chang, H.U.I., Sun, D.Y., Zhou, R.G., Li, B., 2007. Calmodulin-binding protein phosphatase PP7 is involved in thermotolerance in Arabidopsis. Plant Cell Environ. 30 (2), 156-164.

Liu, H.T., Sun, D.Y., Zhou, R.G., 2005. Ca2 + and AtCaM3 are involved in the expression of heat shock protein gene in Arabidopsis. Plant Cell Environ. 28 (10), 1276-1284.

Liu, H.T., Gao, F., Li, G.L., Han, J.L., Liu, D.L., Sun, D.Y., et al., 2008. The calmodulin-binding protein kinase 3 is part of heat-shock signal transduction in Arabidopsis thaliana. Plant J. 55 (5), 760-773.

Locato, V., De Pinto, M.C., De Gara, L., 2009. Different involvement of the mitochondrial, plastidial and cytosolic ascorbate- glutathione redox enzymes in heat shock responses. Physiol. Plant. 135 (3), 296-306.

Masand, S., Yadav, S.K., 2016. Overexpression of MuHSP70 gene from Macrotyloma uniflorum confers multiple abiotic stress tolerance in transgenic Arabidopsis thaliana. Mol. Biol. Rep. 43 (2), 53-64.

Massad, T.J., Dyer, L.A., Vega, G., 2012. Costs of defense and a test of the carbon-nutrient balance and growth-differentiation balance hypotheses for two co-occurring classes of plant defense. PLoS ONE 7 (10), e47554.

Mayer, M., Bukau, B., 2005. Hsp70 chaperones: cellular functions and molecular mechanism. Cell. Mol. Life Sci. 62, 670-684.

Meena, K.K., Sorty, A.M., Bitla, U.M., Choudhary, K., Gupta, P., Pareek, A., et al., 2017. Abiotic stress responses and microbemediated mitigation in plants: the omics strategies. Front. Plant Sci. 8, 172.

Meiri, D., Breiman, A., 2009. Arabidopsis ROF1 (FKBP62) modulates thermotolerance by interacting with HSP90. 1 and affecting the accumulation of HsfA2-regulated sHSPs. Plant J. 59 (3), 387-399.

Miernyk, J.A., 1999. Protein folding in the plant cell. Plant Physiol. 121 (3), 695-703.

Miller, G.A.D., Mittler, R.O.N., 2006. Could heat shock transcription factors function as hydrogen peroxide sensors in plants? Ann. Bot. (Lond.) 98 (2), 279-288.

Miller, G.A.D., Suzuki, N., Ciftci-Yilmaz, S., Mittler, R.O.N., 2010. Reactive oxygen species homeostasis and signalling during drought and salinity stresses. Plant Cell Environ. 33 (4), 453-467.

Miller, G., Shulaev, V., Mittler, R., 2008. Reactive oxygen signalling and abiotic stress. Physiol. Plant. 133 (3), 481-489.

Mirus, O., Schleiff, E., 2009. The evolution of tetratricopeptide repeat domain containing receptors involved in protein translocationreview. Endocytob. Cell Res. (19).

Mishra, R.C., Singh, A., Tiwari, L.D., Grover, A., 2016. Characterization of $5^{\prime}$ UTR of rice ClpB-C/Hsp100 gene: evidence of its involvement in post-transcriptional regulation. Cell Stress Chap. 21 (2), 271-283.

Mishra, S.K., Tripp, J., Winkelhaus, S., Tschiersch, B., Theres, K., Nover, L., et al., 2002. In the complex family of heat stress transcription factors, HsfA1 has a unique role as master regulator of thermotolerance in tomato. Genes Dev. 16 (12), 1555-1567.

Mittler, R., 2002. Oxidative stress, antioxidants and stress tolerance. Trends. Plant. Sci. 7 (9), 405-410.

Mittler, R., Zilinskas, B.A., 1992. Molecular cloning and characterization of a gene encoding pea cytosolic ascorbate peroxidase. J. Biol. Chem. 267 (30), 21802-21807.

Mittler, R., Finka, A., Goloubinoff, P., 2012. How do plants feel the heat? Trends. Biochem. Sci. 37 (3), 118-125.

Mittler, R., Vanderauwera, S., Gollery, M., Van Breusegem, F., 2004. Reactive oxygen gene network of plants. Trends. Plant. Sci. 9 (10), 490-498.

Mogk, A., Schlieker, C., Friedrich, K.L., Schönfeld, H.J., Vierling, E., Bukau, B., 2003. Refolding of substrates bound to small Hsps relies on a disaggregation reaction mediated most efficiently by ClpB/DnaK. J. Biol. Chem. 278 (33), 31033-31042.

Mu, C., Zhang, S., Yu, G., Chen, N., Li, X., Liu, H., 2013. Overexpression of small heat shock protein LimHSP16. 45 in Arabidopsis enhances tolerance to abiotic stresses. PLoS ONE 8 (12), e82264.

Neill, S.J., Desikan, R., Clarke, A., Hurst, R.D., Hancock, J.T., 2002. Hydrogen peroxide and nitric oxide as signalling molecules in plants. J. Exp. Bot. 53 (372), 1237-1247.

Nishizawa, A., Yabuta, Y., Yoshida, E., Maruta, T., Yoshimura, K., Shigeoka, S., 2006. Arabidopsis heat shock transcription factor A2 as a key regulator in response to several types of environmental stress. Plant J. 48 (4), 535-547. 
Nishizawa-Yokoi, A., Tainaka, H., Yoshida, E., Tamoi, M., Yabuta, Y., Shigeoka, S., 2010. The $26 \mathrm{~S}$ proteasome function and Hsp90 activity involved in the regulation of HsfA2 expression in response to oxidative stress. Plant Cell Physiol. 51 (3), 486-496.

Nishizawa-Yokoi, A., Nosaka, R., Hayashi, H., Tainaka, H., Maruta, T., Tamoi, M., et al., 2011. HsfA1d and HsfAle involved in the transcriptional regulation of HsfA2 function as key regulators for the Hsf signalling network in response to environmental stress. Plant Cell Physiol. 52 (5), 933-945.

Nollen, E.A., Morimoto, R.I., 2002. Chaperoning signalling pathways: molecular chaperones as stress-sensing heat shock proteins. J. Cell. Sci. 115 (14), 2809-2816.

Palavan-Unsal, N., Arisan, D., 2009. Nitric oxide signalling in plants. Bot. Rev. 75 (2), 203-229.

Panchuk, I.I., Volkov, R.A., Schöffl, F., 2002. Heat stress-and heat shock transcription factor-dependent expression and activity of ascorbate peroxidase in Arabidopsis. Plant Physiol. 129 (2), 838-853.

Pareek, A., Singla, S.L., Grover, A., 1998. Plant Hsp90 family with special reference to rice. J. Biosci. 23 (4), 361-367.

Parsell, D.A., Lindquist, S., 1993. The function of heat-shock proteins in stress tolerance: degradation and reactivation of damaged proteins. Annu. Rev. Genet. 27 (1), 437-496.

Pastori, G.M., Foyer, C.H., 2002. Common components, networks, and pathways of cross-tolerance to stress. The central role of "redox" and abscisic acid-mediated controls. Plant Physiol. 129 (2), 460-468.

Pavlova, E.L., Rikhvanov, E.G., Tauson, E.L., Varakina, N.N., Gamburg, K.Z., Rusaleva, T.M., et al., 2009. Effect of salicylic acid on the development of induced thermotolerance and induction of heat shock protein synthesis in the Arabidopsis thaliana cell culture. Russian J. Plant Physiol. 56 (1), 68-73.

Per, T.S., Khan, N.A., Reddy, P.S., Masood, A., Hasanuzzaman, M., Khan, M.I.R., et al., 2017. Approaches in modulating proline metabolism in plants for salt and drought stress tolerance: phytohormones, mineral nutrients and transgenics. Plant. Physiol. Biochem. 115, 126-140.

Per, T.S., Khan, M.I.R., Anjum, N.A., Masood, A., Hussain, S.J., Khan, N.A., 2018. Jasmonates in plants under abiotic stresses: crosstalk with other phytohormones matters. Environ. Exp. Bot. 145, 104-120.

Pérez-Salamó, I., Papdi, C., Rigó, G., Zsigmond, L., Vilela, B., Lumbreras, V., et al., 2014. The heat shock factor A4A confers salt tolerance and is regulated by oxidative stress and the mitogenactivated protein kinases MPK3 and MPK6. Plant Physiol. 165 (1), 319-334.

Pnueli, L., Liang, H., Rozenberg, M., Mittler, R., 2003. Growth suppression, altered stomatal responses, and augmented induction of heat shock proteins in cytosolic ascorbate peroxidase (Apx1)-deficient Arabidopsis plants. Plant J. 34 (2), 187-203.

Poovaiah, B.W., Reddy, A.S.N., Feldman, L., 1993. Calcium and signal transduction in plants. CRC. Crit. Rev. Plant. Sci. 12 (3), 185-211.

Prasad, T.K., Anderson, M.D., Martin, B.A., Stewart, C.R., 1994. Evidence for chilling-induced oxidative stress in maize seedlings and a regulatory role for hydrogen peroxide. Plant Cell 6 (1), 65-74.

Pratt, W.B., Toft, D.O., 2003. Regulation of signalling protein function and trafficking by the hsp $90 /$ hsp70-based chaperone machinery. Exp. Biol. Med. 228 (2), 111-133.

Pratt, W.B., Galigniana, M.D., Harrell, J.M., DeFranco, D.B., 2004. Role of hsp90 and the hsp90-binding immunophilins in signalling protein movement. Cell. Signal. 16 (8), 857-872.

Pucciariello, C., Banti, V., Perata, P., 2012. ROS signalling as common element in low oxygen and heat stresses. Plant. Physiol. Biochem. 59, 3-10.

Pulyaevskaya, M.A., Varakina, N.N., Gamburg, K.Z., Rusaleva, T.M., Stepanov, A.V., Voinikov, V.K., et al., 2011. Sodium fluoride inhibits HSP synthesis in heat-stressed cultured cells of Arabidopsis thaliana. Russian J. Plant Physiol. 58 (4), 589-596.

Pyatrikas, D.V., Rikhvanov, E.G., Fedoseeva, I.V., Varakina, N.N., Rusaleva, T.M., Tauson, E.L., et al., 2014. Mitochondrial retrograde regulation of HSP101 expression in Arabidopsis thaliana under heat stress and amiodarone action. Russian J. Plant Physiol. 61 (1), 80-89.

Qiu, X.B., Shao, Y.M., Miao, S., Wang, L., 2006. The diversity of the DnaJ/Hsp40 family, the crucial partners for Hsp70 chaperones. Cell. Mol. Life Sci. CMLS 63 (22), 2560-2570.

Queitsch, C., Hong, S.W., Vierling, E., Lindquist, S., 2000. Heat shock protein 101 plays a crucial role in thermotolerance in Arabidopsis. Plant Cell 12 (4), 479-492.

Rasmussen, S., Barah, P., Suarez-Rodriguez, M.C., Bressendorff, S., Friis, P., Costantino, P., et al., 2013. Transcriptome responses to combinations of stresses in Arabidopsis. Plant Physiol. 161 (4), 1783-1794.

Reddy, A.S., Ali, G.S., Celesnik, H., Day, I.S., 2011. Coping with stresses: roles of calcium-and calcium/calmodulin-regulated gene expression. Plant Cell 23 (6), 2010-2032.

Reddy P.S., Chakradhar T., Reddy R.A., Nitnavare R.B., Mahanty S., Reddy M.K., 2016. Role of Heat Shock Proteins in Improving Heat Stress Tolerance in Crop Plants. In Heat Shock Proteins and Plants, Springer, Cham, 283-307.

Reddy, P.S., Mallikarjuna, G., Kaul, T., Chakradhar, T., Mishra, R.N., Sopory, S.K., et al., 2010. Molecular cloning and characterization of gene encoding for cytoplasmic Hsc70 from Pennisetum glaucum may play a protective role against abiotic stresses. Mol. Genet. Genomics. 283 (3), 243-254.

Reddy, P.S., Thirulogachandar, V., Vaishnavi, C.S., Aakrati, A., Sopory, S.K., Reddy, M.K., 2011. Molecular characterization and expression of a gene encoding cytosolic Hsp90 from Pennisetum glaucum and its role in abiotic stress adaptation. Gene 474 (1), 29-38.

Reddy, P.S., Kishor, P.B.K., Seiler, C., Kuhlmann, M., EschenLippold, L., Lee, J., et al., 2014a. Unraveling regulation of the small heat shock proteins by the heat shock factor $\mathrm{HvHsfB} 2 \mathrm{c}$ in barley: its implications in drought stress response and seed development. PLoS ONE 9 (3), e89125.

Reddy, P.S., Vadez, V., Nese, S., Kishor, P.K., 2014b. Tackling the heat-stress tolerance in crop plants: a bioinformatics approach. Agricultural Bioinformatics. Springer, India, pp. 33-57.

Reddy, P.S., Sharma, K.K., Vadez, V., Reddy, M.K., 2015. Molecular cloning and differential expression of cytosolic class I small Hsp gene family in Pennisetum glaucum (L.). Appl. Biochem. Biotechnol. 176 (2), 598-612.

Reddy, R.A., Kumar, B., Reddy, P.S., Mishra, R.N., Mahanty, S., Kaul, T., et al., 2009. Molecular cloning and characterization of genes encoding Pennisetum glaucum ascorbate peroxidase and heat-shock factor: interlinking oxidative and heat-stress responses. J. Plant. Physiol. 166 (15), 1646-1659.

Rikhvanov, E.G., Gamburg, K.Z., Varakina, N.N., Rusaleva, T.M., Fedoseeva, I.V., Tauson, E.L., et al., 2007. Nuclear-mitochondrial cross-talk during heat shock in Arabidopsis cell culture. Plant J. 52 (4), 763-778.

Rousch, J.M., Bingham, S.E., Sommerfeld, M.R., 2004. Protein expression during heat stress in thermo-intolerant and thermo-tolerant diatoms. J. Exp. Mar. Bio. Ecol. 306 (2), 231-243.

Saidi, Y., Finka, A., Muriset, M., Bromberg, Z., Weiss, Y.G., Maathuis, F.J., et al., 2009. The heat shock response in moss plants is regulated by specific calcium-permeable channels in the plasma membrane. Plant Cell 21, 2829-2843.

Saidi, Y., Finka, A., Goloubinoff, P., 2011. Heat perception and signalling in plants: a tortuous path to thermotolerance. New Phytol. 190 (3), 556-565. 
Sakurai, H., Enoki, Y., 2010. Novel aspects of heat shock factors: DNA recognition, chromatin modulation and gene expression. FEBS. J. 277 (20), 4140-4149.

Samakovli, D., Margaritopoulou, T., Prassinos, C., Milioni, D., Hatzopoulos, P., 2014. Brassinosteroid nuclear signalling recruits HSP90 activity. New Phytol. 203 (3), 743-757.

Sangwan, V., Örvar, B.L., Beyerly, J., Hirt, H., Dhindsa, R.S., 2002. Opposite changes in membrane fluidity mimic cold and heat stress activation of distinct plant MAP kinase pathways. Plant J. $31(5), 629-638$.

Sasabe, M., Soyano, T., Takahashi, Y., Sonobe, S., Igarashi, H., Itoh, T.J., et al., 2006. Phosphorylation of NtMAP65-1 by a MAP kinase down-regulates its activity of microtubule bundling and stimulates progression of cytokinesis of tobacco cells. Genes Dev. 20 (8), 1004-1014.

Sato, S., Fujita, N., Tsuruo, T., 2000. Modulation of Akt kinase activity by binding to Hsp90. Proc. Natl. Acad. Sci. 97 (20), 10832-10837.

Scarpeci, T.E., Zanor, M.I., Carrillo, N., Mueller-Roeber, B., Valle, E. M., 2008. Generation of superoxide anion in chloroplasts of Arabidopsis thaliana during active photosynthesis: a focus on rapidly induced genes. Plant Mol. Biol. 66 (4), 361-378.

Scharf, K.D., Rose, S., Zott, W., Schöffl, F., Nover, L., Schöff, F., 1990. Three tomato genes code for heat stress transcription factors with a region of remarkable homology to the DNA-binding domain of the yeast HSF. EMBO J. 9 (13), 4495-4501.

Scharf, K.D., Höhfeld, I., Nover, L., 1998. Heat stress response and heat stress transcription factors. J. Biosci. 23 (4), 313.

Scharf, K.D., Berberich, T., Ebersberger, I., Nover, L., 2012. The plant heat stress transcription factor (Hsf) family: structure, function and evolution. Biochimica et Biophysica Acta (BBA)-Gene Regul. Mech. 1819 (2), 104-119.

Schramm, F., Larkindale, J., Kiehlmann, E., Ganguli, A., Englich, G., Vierling, E., et al., 2008. A cascade of transcription factor DREB2A and heat stress transcription factor HsfA3 regulates the heat stress response of Arabidopsis. Plant J. 53 (2), 264-274.

Schroda, M., Vallon, O., Wollman, F.A., Beck, C.F., 1999. A chloroplast-targeted heat shock protein 70 (HSP70) contributes to the photoprotection and repair of photosystem II during and after photoinhibition. Plant Cell 11 (6), 1165-1178.

Seo, H.R., Chung, D.Y., Lee, Y.J., Lee, D.H., Kim, J.I., Bae, S., et al., 2006. Heat shock protein 25 or inducible heat shock protein 70 activates heat shock factor 1 dephosphorylation on serine 307 through inhibition of ERK1/2 phosphorylation. J. Biol. Chem. 281 (25), 17220-17227.

Shao, H.B., Chu, L.Y., Jaleel, C.A., Zhao, C.X., 2008. Water-deficit stress-induced anatomical changes in higher plants. C. R. Biol. 331 (3), 215-225.

Simons, G., Groenendijk, J., Wijbrandi, J., Reijans, M., Groenen, J., Diergaarde, P., et al., 1998. Dissection of the Fusarium I2 gene cluster in tomato reveals six homologs and one active gene copy. Plant Cell 10 (6), 1055-1068.

Singh, A., Grover, A., 2010. Plant Hsp100/ClpB-like proteins: poorlyanalyzed cousins of yeast ClpB machine. Plant Mol. Biol. 74 (4-5), 395-404.

Sinha, A.K., Jaggi, M., Raghuram, B., Tuteja, N., 2011. Mitogenactivated protein kinase signalling in plants under abiotic stress. Plant Signal. Behav. 6 (2), 196-203.

Song, A., Zhu, X., Chen, F., Gao, H., Jiang, J., Chen, S., 2014. A chrysanthemum heat shock protein confers tolerance to abiotic stress. Int. J. Mol. Sci. 15 (3), 5063-5078.

Song, X., Xu, A., Pan, W., Wallin, B., Kivlin, R., Lu, S., et al., 2008. Minocycline protects melanocytes against $\mathrm{H} 2 \mathrm{O} 2$-inducedcell death via JNK and p38 MAPK pathways. Int. J. Mol. Med. 22 (1), 9-16.

Storozhenko, S., De Pauw, P., Van Montagu, M., Inzé, D., Kushnir, S., 1998. The heat-shock element is a functional component of the
Arabidopsis APX1 gene promoter. Plant Physiol. 118 (3), 1005-1014.

Su, P.H., Li, H.M., 2008. Arabidopsis stromal 70-kD heat shock proteins are essential for plant development and important for thermotolerance of germinating seeds. Plant Physiol. 146 (3), 1231-1241.

Sugio, A., Dreos, R., Aparicio, F., Maule, A.J., 2009. The cytosolic protein response as a subcomponent of the wider heat shock response in Arabidopsis. Plant Cell 21 (2), 642-654.

Sun, J., Zhang, C.L., Deng, S.R., Lu, C.F., Shen, X., Zhou, X.Y., et al., 2012. An ATP signalling pathway in plant cells: extracellular ATP triggers programmed cell death in Populus euphratica. Plant Cell Environ. 35 (5), 893-916.

Sun, W., Van Montagu, M., Verbruggen, N., 2002. Small heat shock proteins and stress tolerance in plants. Biochimica et Biophysica Acta (BBA)-Gene Struct. Exp. 1577 (1), 1-9.

Sun, X.T., Li, B., Zhou, G.M., Tang, W.Q., Bai, J., Sun, D.Y., et al., 2000. Binding of the maize cytosolic Hsp70 to calmodulin, and identification of calmodulin-binding site in Hsp70. Plant Cell Physiol. 41 (6), 804-810.

Sun, X., Sun, C., Li, Z., Hu, Q., Han, L., Luo, H., 2016. AsHSP17, a creeping bentgrass small heat shock protein modulates plant photosynthesis and ABA-dependent and independent signalling to attenuate plant response to abiotic stress. Plant Cell Environ. 39 (6), 1320-1337.

Suri, S.S., Dhindsa, R.S., 2008. A heat-activated MAP kinase (HAMK) as a mediator of heat shock response in tobacco cells. Plant Cell Environ. 31 (2), 218-226.

Suzuki, N., Rizhsky, L., Liang, H., Shuman, J., Shulaev, V., Mittler, R., 2005. Enhanced tolerance to environmental stress in transgenic plants expressing the transcriptional coactivator multiprotein bridging factor 1c. Plant Physiol. 139 (3), 1313-1322.

Suzuki, N., Sejima, H., Tam, R., Schlauch, K., Mittler, R., 2011. Identification of the MBF1 heat-response regulon of Arabidopsis thaliana. Plant J. 66 (5), 844-851.

Suzuki, N., Koussevitzky, S., Mittler, R.O.N., Miller, G.A.D., 2012. ROS and redox signalling in the response of plants to abiotic stress. Plant Cell Environ. 35 (2), 259-270.

Swindell, W.R., Huebner, M., Weber, A.P., 2007. Transcriptional profiling of Arabidopsis heat shock proteins and transcription factors reveals extensive overlap between heat and non-heat stress response pathways. BMC Genomics 8 (1), 125.

Szyszka, R., Kramer, G., Hardesty, B., 1989. The phosphorylation state of the reticulocyte $90-\mathrm{kDa}$ heat shock protein affects its ability to increase phosphorylation of peptide initiation factor 2 . alpha. subunit by the heme-sensitive kinase. Biochemistry 28 (4), 1435-1438.

Tena, G., Asai, T., Chiu, W.L., Sheen, J., 2001. Plant mitogenactivated protein kinase signalling cascades. Curr. Opin. Plant. Biol. 4 (5), 392-400.

Timperio, A.M., Egidi, M.G., Zolla, L., 2008. Proteomics applied on plant abiotic stresses: role of heat shock proteins (HSP). J. Proteomics. 71 (4), 391-411.

Tompa, P., Kovacs, D., 2010. Intrinsically disordered chaperones in plants and animals. Biochem. Cell. Biol. 88 (2), 167-174.

Török, Z., Goloubinoff, P., Horváth, I., Tsvetkova, N.M., Glatz, A., Balogh, G., et al., 2001. Synechocystis HSP17 is an amphitropic protein that stabilizes heat-stressed membranes and binds denatured proteins for subsequent chaperone-mediated refolding. Proc. Natl. Acad. Sci. 98 (6), 3098-3103.

Tripp, J., Mishra, S.K., Scharf, K.D., 2009. Functional dissection of the cytosolic chaperone network in tomato mesophyll protoplasts. Plant Cell Environ. 32 (2), 123-133.

Tuteja, N., 2009. Integrated calcium signalling in plants. Signalling in plants. Springer Berlin Heidelberg, pp. 29-49. 
Tuteja, N., Sopory, S.K., 2008. Chemical signalling under abiotic stress environment in plants. Plant Signal. Behav. 3 (8), 525-536.

Udvardi, M.K., Kakar, K., Wandrey, M., Montanari, O., Murray, J., Andriankaja, A., et al., 2007. Legume transcription factors: global regulators of plant development and response to the environment. Plant Physiol. 144 (2), 538-549.

Usman, M.G., Rafii, M.Y., Ismail, M.R., Malek, M.A., Latif, M.A., Oladosu, Y., 2014. Heat shock proteins: functions and response against heat stress in plants. Int. J. Sci. Technol. Res 3 (11), 204-218.

Vij, S., Tyagi, A.K., 2007. Emerging trends in the functional genomics of the abiotic stress response in crop plants. Plant. Biotechnol. J. 5 (3), 361-380.

Vinocur, B., Altman, A., 2005. Recent advances in engineering plant tolerance to abiotic stress: achievements and limitations. Curr. Opin. Biotechnol. 16 (2), 123-132.

Voellmy, R., Boellmann, F., 2007. Chaperone regulation of the heat shock protein response. Molecular Aspects of the Stress Response: Chaperones, Membranes and Networks. Springer, New York, NY, pp. 89-99.

Volkov, R.A., Panchuk, I.I., Mullineaux, P.M., Schöffl, F., 2006. Heat stress-induced $\mathrm{H} 2 \mathrm{O} 2$ is required for effective expression of heat shock genes in Arabidopsis. Plant Mol. Biol. 61 (4-5), 733-746.

von Koskull-Döring, P., Scharf, K.D., Nover, L., 2007. The diversity of plant heat stress transcription factors. Trends. Plant. Sci. 12 (10), 452-457.

Wan, X.L., Yang, J., Li, X.B., Zhou, Q., Guo, C., Bao, M.Z., et al., 2016. Over-expression of PmHSP17. 9 in transgenic Arabidopsis thaliana confers thermotolerance. Plant. Mol. Biol. Rep. 34 (5), 899-908.

Wang, A., Yu, X., Mao, Y., Liu, Y., Liu, G., Liu, Y., et al., 2015. Overexpression of a small heat-shock-protein gene enhances tolerance to abiotic stresses in rice. Plant Breeding 134 (4), 384-393.

Wang, R., Zhang, Y., Kieffer, M., Yu, H., Kepinski, S., Estelle, M., 2016. HSP90 regulates temperature-dependent seedling growth in Arabidopsis by stabilizing the auxin co-receptor F-box protein TIR1. Nat. Commun. 7, 10269.

Wang, W., Vinocur, B., Altman, A., 2003. Plant responses to drought, salinity and extreme temperatures: towards genetic engineering for stress tolerance. Planta 218 (1), 1-14.

Wang, W., Vinocur, B., Shoseyov, O., Altman, A., 2004. Role of plant heat-shock proteins and molecular chaperones in the abiotic stress response. Trends. Plant. Sci. 9 (5), 244-252.

Wang, X., Huang, B., 2017. Lipid-and calcium-signalling regulation of HsfA2c-mediated heat tolerance in tall fescue. Environ. Exp. Bot. 136, 59-67.

Wang, Y., Lin, S., Song, Q., Li, K., Tao, H., Huang, J., et al., 2014. Genome-wide identification of heat shock proteins (Hsps) and Hsp interactors in rice: Hsp70s as a case study. BMC Genomics 15 (1), 344

Wegele, H., Müller, L., Buchner, J., 2004. Hsp70 and Hsp90-a relay team for protein folding. Reviews of physiology, biochemistry and pharmacology. Springer Berlin Heidelberg, pp. 1-44.

Weir, I.E., Pham, N.A., Hedley, D.W., 2003. Oxidative stress is generated via the mitochondrial respiratory chain during plant cell apoptosis. Cytom. Part A 54 (2), 109-117.

Wurzinger, B., Mair, A., Pfister, B., Teige, M., 2011. Cross-talk of calcium-dependent protein kinase and MAP kinase signalling. Plant Signal. Behav. 6 (1), 8-12.

Xiong, L., Schumaker, K.S., Zhu, J.K., 2002. Cell signaling during cold, drought, and salt stress. Plant Cell 14 (Suppl. 1), S165-S183.

Xu, J., Xue, C., Xue, D., Zhao, J., Gai, J., Guo, N., et al., 2013. Overexpression of GmHsp90s, a heat shock protein 90 (Hsp90) gene family cloning from soybean, decrease damage of abiotic stresses in Arabidopsis thaliana. PLoS ONE 8 (7), e69810.
Xu, Q., Metzler, B., Jahangiri, M., Mandal, K., 2012. Molecular chaperones and heat shock proteins in atherosclerosis. Am. J. Physiol. Heart Circul. Physiol. 302 (3), H506-H514.

Xuan, Y., Zhou, S., Wang, L., Cheng, Y., Zhao, L., 2010. Nitric oxide functions as a signal and acts upstream of AtCaM3 in thermotolerance in Arabidopsis seedlings. Plant Physiol. 153 (4), 1895-1906.

Xue, G.P., Drenth, J., McIntyre, C.L., 2014. TaHsfA6f is a transcriptional activator that regulates a suite of heat stress protection genes in wheat (Triticum aestivum L.) including previously unknown Hsf targets. J. Exp. Bot. 66 (3), 1025-1039.

Yamada, K., Fukao, Y., Hayashi, M., Fukazawa, M., Suzuki, I., Nishimura, M., 2007. Cytosolic HSP90 regulates the heat shock response that is responsible for heat acclimation in Arabidopsis thaliana. J. Biol. Chem. 282 (52), 37794-37804.

Yoshida, T., Mogami, J., Yamaguchi-Shinozaki, K., 2014. ABAdependent and ABA-independent signalling in response to osmotic stress in plants. Curr. Opin. Plant. Biol. 21, 133-139.

Yoshida, T., Sakuma, Y., Todaka, D., Maruyama, K., Qin, F., Mizoi, J., et al., 2008. Functional analysis of an Arabidopsis heat-shock transcription factor HsfA3 in the transcriptional cascade downstream of the DREB2A stress-regulatory system. Biochem. Biophys. Res. Commun. 368 (3), 515-521.

Yu, A., Li, P., Tang, T., Wang, J., Chen, Y., Liu, L., 2015. Roles of Hsp70s in stress responses of microorganisms, plants, and animals. Biomed. Res. Int. 2015.

Zabaleta, E., Oropeza, A., Assad, N., Mandel, A., Salerno, G., Herrera-Estrella, L., 1994. Antisense expression of chaperonin 603 in transgenic tobacco plants leads to abnormal phenotypes and altered distribution of photoassimilates. Plant J. 6 (3), 425-432.

Zhang, H., Li, L., Ye, T., Chen, R., Gao, X., Xu, Z., 2016. Molecular characterization, expression pattern and function analysis of the OsHSP90 family in rice. Biotechnol. Biotechnol. Equip. 30 (4), 669-676.

Zhang, J.H., Wang, L.J., Pan, Q.H., Wang, Y.Z., Zhan, J.C., Huang, W.D., 2008. Accumulation and subcellular localization of heat shock proteins in young grape leaves during cross-adaptation to temperature stresses. Sci. Hortic. (Amsterdam) 117 (3), $231-240$.

Zhang, W., Zhou, R.G., Gao, Y.J., Zheng, S.Z., Xu, P., Zhang, S.Q., et al., 2009. Molecular and genetic evidence for the key role of AtCaM3 in heat-shock signal transduction in Arabidopsis. Plant Physiol. 149 (4), 1773-1784.

Zhang, Y., Dorey, S., Swiderski, M., Jones, J.D., 2004. Expression of RPS4 in tobacco induces an AvrRps4-independent HR that requires EDS1, SGT1 and HSP90. Plant J. 40 (2), 213-224.

Zhou, L., Liu, Z., Liu, Y., Kong, D., Li, T., Yu, S., et al., 2016. A novel gene OsAHL1 improves both drought avoidance and drought tolerance in rice. Sci. Rep. 6, 30264.

Zhou, Y., Chen, H., Chu, P., Li, Y., Tan, B., Ding, Y., et al., 2012b. NnHSP17.5, a cytosolic class II small heat shock protein gene from Nelumbo nucifera, contributes to seed germination vigor and seedling thermotolerance in transgenic Arabidopsis. Plant Cell Rep. 31 (2), 379-389.

Zou, J., Liu, C., Liu, A., Zou, D., Chen, X., 2012. Overexpression of OsHsp17. 0 and OsHsp23. 7 enhances drought and salt tolerance in rice. J. Plant. Physiol. 169 (6), 628-635.

Zhu, B., Ye, C., Lü, H., Chen, X., Chai, G., Chen, J., et al., 2006. Identification and characterization of a novel heat shock transcription factor gene, GmHsfA1, in soybeans (Glycine max). J. Plant. Res. 119 (3), 247-256.

Zuehlke, A., Johnson, J.L., 2010. Hsp90 and co-chaperones twist the functions of diverse client proteins. Biopolymers 93 (3), 211-217. 